\title{
Oluf Wolf og den franske forbindelse
}

\section{En sønderjysk spionagesag under 1. Verdenskrig}

\author{
Af MORTEN ANDERSEN
}

Omkring 2.500 sønderjyder deserterede fra tysk krigstjeneste under 1 . Verdenskrig. Desertører, der havde gjort fronttjeneste, sad inde med værdifuld viden om forhold i Tyskland og ved den tyske front, som Ententemagterne Frankrig, England og Rusland kunne have gavn af. På den baggrund opstod der et spionagenetværk nord for Kongeåen, hvis formål var at indsamle oplysninger fra de deserterede sønderjyder. En af de involverede var gårdejer Oluf Peter Wolf fra Diernæs, forfatterens oldefar, for hvem spionagedeltagelsen blev skæbnesvanger. ${ }^{1}$

I Sønderjylland betragtes 1. Verdenskrig som Den Store Krig. Det gør den, fordi omkring 35.000 mand fra det Sønderjylland, der i $1920 \mathrm{blev}$ genforenet med Danmark, deltog i krigen som soldater. Og det gør den, fordi omkring 5.270 sønderjyske mænd faldt i krigen, og andre 4.000 kom hjem som krigsinvalider. Krigen førte efterfølgende til Sønderjyllands genforening med Danmark og fik dermed afgørende betydning for Sønderjyllands historie. I mange sønderjyske familier er 1. Verdenskrig derfor et særligt kapitel af historien, hvortil der også knytter sig særlige familie-historier. Min familie bærer også på en særlig historie med tilknytning til Den Store Krig. Historien omhandler min oldefar på fædrene side, Oluf Peter Wolf (1880-1943), fra Diernæs ved Hoptrup, der ikke deltog i krigen, men som valgte at gå over Kongeåen for at undgå tysk krigstjeneste.

\section{Oluf Peter Wolf}

Oluf Peter Wolf blev født på gården Skærbæk mellem Hoptrup og Diernæs den 28. december 1880. Gården, med udsigt over Slivsø, havde været i slægtens eje siden 1832. Hans Christian Wolf, Olufs far, overtog gården i 1863 og blev samme år gift med Cathrine Marie Dall 


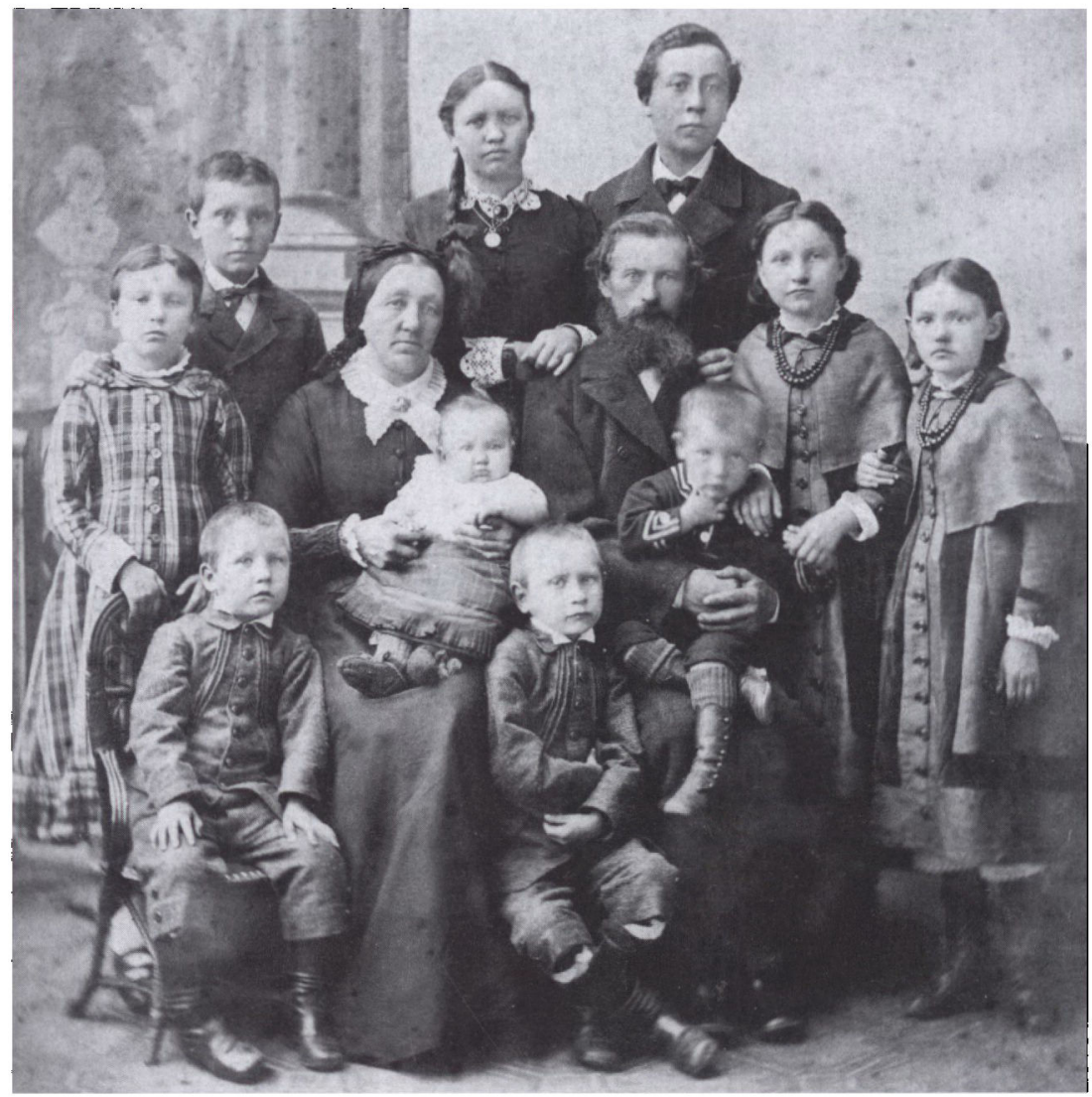

Hans Christian og Cathrine Marie Wolf med 10 børn $i$ 1883. Oluf på 3 år sidder $p a ̊$ sin fars skød. Privat foto.

fra Kestrup nord for Slivsø. Cathrine Maries far, Bertel Wollesen Dall, havde deltaget $\mathrm{i}$ den første Skamlingsbankefest den 18. maj 1843 og var blandt de forste medlemmer af Den Slesvigske Forening. ${ }^{2} \mathrm{Ca}$ thrine Marie medbragte fra sin far et »dansk-slesvigsk « sindelag, der skulle komme til at præge familien og ikke mindst Oluf, der var barn nummer 11 i en række på 13, hvoraf to døde som spæd. Yderligere tre søskende døde ganske unge. Året 1899 var særlig barskt, da to søskende døde af tuberkulose henholdsvis 16 og 13 år gamle. I 1889 emigrerede Olufs storebroder, Bertel Wolf, kun 16 år gammel til Californien. I 1908 fulgte broderen Hans Christian, der efter en tur over Argentina også endte i Californien. De to brødre fulgte de omtrent 
60.000 sønderjyder, der emigrerede i tiden mellem 1864 og 1920. Da Olufs ældste broder, Jørgen Wolf, havde startet sit eget landbrug i Moltrup, stod den ældste tilbageværende broder, Frederik Boisen Wolf, til at overtage gården. ${ }^{3}$ Men i 1903 døde også Frederik af tuberkulose, som han havde pådraget sig under sin værnepligt i Posen. Det fik på flere måder betydning for Olufs levnedsforløb.

Oluf blev indkaldt til session i år 1900. Han fik tilsyneladende udsat sin værnepligt i to omgange, før han i 1903 blev fritaget. I hans indførsel i den alfabetiske liste for Diernæs står der tilføjet, at to søskende var døde af tuberkulose. ${ }^{4}$ Det er formentlig Frederiks død i 1903 samt den yngste søster Dagmar Margrethes død i 1899, der henvises til, og som har været udslagsgivende for fritagelsen. Under alle omstændigheder slap Oluf for værnepligten og kunne i stedet tage på Askov Højskole i to omgange, først i 1902 og igen i foråret 1904. I mellemtiden havde Oluf fundet sin udkårne. Anne Margrethe Johansen fra Fjelstrup og Oluf Wolf blev forlovet under det fælles ophold på Askov Højskole i foråret $1904 \mathrm{og}$ blev viet i Fjelstrup kirke den 9. juni 1906. Broderen Frederiks død i 1903 betød også, at Oluf var den eneste tilbageværende søn på gården Skærbæk, og at han derfor måtte overtage gården. Efter brylluppet i juni 1906 kunne Oluf og Margrethe derfor flytte ind på Skærbæk som gårdmandspar. ${ }^{5}$

Som omtalt var Oluf vokset op i et dansksindet hjem under særlig indflydelse af sin moder Cathrine Marie. Familien havde været en del af den kreds, der dannede en dansk grundtvigiansk frimenighed $i$ Haderslev i 1895, og som opførte Kristuskirken. Tilknytningen til frimenigheden bevarede Oluf og Margrethe, og fem af parrets seks børn blev døbt i Kristuskirken eller af frimenighedspræsten Thade Petersen i hjemmet. ${ }^{6}$ Oluf medvirkede også i opførelsen af det danske forsamlingshus i Hoptrup, det senere Hoptruphus, der blev indviet $i$ januar 1908. I den anledning blev Selskabelig Forening for Hoptrup og Omegn stiftet, og Oluf blev foreningens forste formand. Som sådan skulle Oluf anmelde de "politiske« arrangementer, som foreningen arrangerede, til amtsforstander for Hoptrup amtsdistrikt, Jacob Riis i Diernæs. I foråret 1908 henvendte Oluf Wolf sig til H.P.Hanssen med henblik på at få rigsdagsmanden til at tale ved et offentligt møde i forsamlingshuset, »da de endnu ikke har besøgt vort Forsamlingshus, og da Folk her paa Egnen i det hele taget er meget lidt personlig kendt med Dem «. ${ }^{7}$ Søndag den 10. januar 1909 kunne Selskabelig Forening for Hoptrup og Omegn præsentere H.P.Hanssen som taler i 
Hoptrup Forsamlingshus. Forsamlingshuset blev udgangspunkt for endnu en forening, da Idrætsforening for Hoptrup og omegn blev stiftet $\mathrm{i}$ juli 1908. Oluf Wolf blev også denne forenings første formand. ${ }^{8}$ Der var engagement og energi i den unge gårdmand, og det var den danske sag, der var drivkraften. Som Oluf skrev til Margrethe i Fjelstrup i juni 1903: "Nu er der jo ogsaa andet, der lægger Beslag paa ens Tanker; thi det staar klart for mig, at vor store Folkesag, den vil jeg vie mine bedste Kræfter; noget maa man have at kæmpe for, det gælder blot om, at det er noget godt, og det er der ikke Spor af Tvivl om, at det er «. ${ }^{9}$

\section{Faneflugt}

Der var ikke spor af tvivl om familien Wolfs ståsted i den nationale konflikt, som efterhånden var blevet allestedsnærværende i Sønderjylland. Krigens udbrud i august 1914 førte heller ikke kun til ængstelse i familien, men også til et håb om, at forandringer kunne være undervejs. Håbet skulle vise sig at holde stik, men prisen skulle vise sig at blive meget høj for Sønderjylland såvel som for familien Wolf. I første omgang berørte krigen ikke familien direkte, da Oluf ikke havde aftjent værnepligt og dermed ikke skulle stille til krigstjeneste. Men krigens forlængelse betød, at den tyske hær efterhånden fik brug for flere soldater. Og i juni 1915 kom der også bud efter Oluf Wolf.

Ved krigsudbruddet $\mathrm{i}$ august 1914 havde der ikke fundet deserteringer sted fra Nordslesvig, hvad der ellers var frygtet af de tyske myndigheder. Den danske bevægelses officielle holdning til pligtspørgsmålet var også, at nordslesvigerne skulle opfylde deres pligt og dermed gå i tysk krigstjeneste for at bevare den danske bevægelses status som nationalt mindretal under det tyske herredømme. Som H.P.Hanssen skrev i avisen Hejmdal den 7. august 1914: »Vi er og har altid været overbeviste om, at ligesaa energisk som de danske Nordslesvigere altid har krævet deres statsborgerlige Rettigheder respekterede, ligesaa samvittighedsfuldt vil de opfylde deres statsborgerlige Pligter i disse alvorlige Tider « ${ }^{10}$ Det forblev den officielle holdning krigen igennem, uden at Vælgerforeningen for Nordslesvig offentligt fordømte desertørerne, da de tog til i antal efterhånden, som krigen trak ud. Blandt den dansksindede befolkning i Nordslesvig var holdningen mere blandet. Alle ønskede naturligvis, at deres nære overlevede krigen, og chancen derfor blev i sagens natur større ved 
at undgå krigstjeneste. Men forøgede desertørerne ikke samtidig risikoen for dem, der giorde deres pligt? Eller fratog desertørerne ikke de pligtopfyldende muligheden for orlov, fordi den tyske hær ikke ville risikere yderligere deserteringer? Argumentet blev rejst imod desertørerne, og argumentet skulle blive taget op igen, da krigen var slut. ${ }^{11}$

For Oluf og Margrethe Wolf var valget mellem pligt eller flugt tilsyneladende ikke vanskelig. Det ser i hvert fald ud til, at beslutningen var taget, da Olufs mødeindkaldelse kom i juni 1915, for samme aften tog Oluf over Kongeåen. Hvilken rute han tog, eller præcis hvorledes grænseovergangen forløb, vides ikke, men omkring klokken 1 om natten modtog Margrethe besked om, at Oluf var i sikkerhed. At der skulle gå 4 år, før Oluf kom hjem igen, var familien lykkeligt uvidende om, men savnet blev også stort nok i sig selv. Som mange andre sønderjyske gårdfruer måtte Margrethe tage ansvaret for driften af gården, mens manden var borte. Olufs fader, Hans Christian Wolf, var på gården, men var 79 år gammel. Som på andre gårde blev der i løbet af krigen stillet krigsfanger til rådighed, fortrinsvis russiske. Det meste af krigen havde Margrethe således gavn af russeren Sabatin. Krigens knaphed fik familien også at føle. Forskellen på en taksation af ejendommen i 1916 og et regnskab af 1911 taler sit tydelige sprog. Husdyrholdet var reduceret fra 13 til 3 malkekøer, fra 43 til 3 svin og fra 7 til 3 heste. Det var et ganske godt billede på den realisering af værdier, der fandt sted i det sønderjyske landbrug under krigen som et resultat af tvangsafleveringer og generel knaphed på fødevarer. Af gårdens godt 37 ha landbrugsjord var 2 ha desuden blevet inddraget til befæstningsbyggeri. Fæstningsanlægget »Sikringsstilling Nord «, der gik tværs over Nordslesvig, blev netop påbegyndt i efteråret 1916 og havde sit østlige udspring ved Hoptrup og Slivsø. ${ }^{12}$ De stadig sværere driftsforhold og dertil fem børn måtte Margrethe håndtere på egen hånd, mens Oluf forsøgte at skabe sig en tilværelse uden familien nord for Kongeåen.

Oluf Wolf opholdt sig det meste af sin landflygtighed i Kolding nær ved grænsen. Her kunne Margrethe og børnene jævnligt komme på besøg, og kontakten til familien blev herved opretholdt. Ifølge Margrethe krævede besøgene lidt madvarer, flæsk eller smør til de tyske grænsevagter for at slippe over grænsen. Ved enkelte lejligheder mødtes familien og Oluf ved Hejlsminde for at vinke til hinanden fra hver sin side af Hejlsminde Nor. Oluf vovede sig derimod ikke til Diernæs, hvor en 


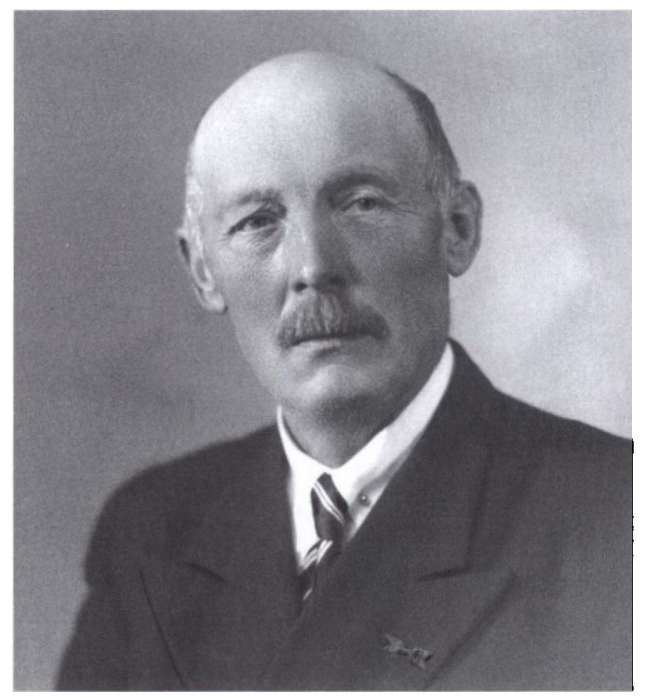

Oluf Wolf $i$ et portræt fra $1930^{\prime}$ erne. Privat foto.

længere fængselsstraf eller sågar dødsstraf kunne være i vente. I første omgang tog Oluf ophold som bestyrer på Pjengaard ved Højen nær Vejle. Herefter havde han et 5 måneders ophold på Landbrugsskolen Næsgaard ved Stubbekøbing. Fra april 1916 opholdt han sig i Kolding by, hvor han $i$ en periode fandt beskæftigelse som regnskabsfører for kreaturkommissionsfirmaet Ravn \& Eriksen. I perioder arbejdede han også som landbrugsmedhjælper på gårde i området.

Mange sønderjyske faneflygtninge opholdt sig i grænseområdet for som Oluf at være så nær på familien som muligt. Der var derfor rig mulighed for at finde sammen med bekendte i området. Også for Oluf Wolf, som $\mathrm{i}$ en periode arbejdede sammen med to bekendte, Jes Hansen fra Fjelstrup og Theodor Mathiesen Kylling fra Frørup. Bekendtskabet med Kylling, der senere blev en aktiv skikkelse i de sønderjyske bondeprotestbevægelser, skulle få afgørende betydning for Olufs skæbne. Tilstedeværelsen af de mange sønderjyske faneflygtninge i Kolding-området gav også anledning til en foreningsdannelse. Den 10. september 1916 blev foreningen Vort Hjemlands Vel stiftet på et møde i Lunderskov, og den 26. september blev foreningen godkendt af »talrige Sønderjyder« ved et opfølgende møde i Kolding. Oluf Wolf blev foreningens formand, Peter Mink fra Haderslev næstformand, og cand.theol. Holger Andersen, under krigen bosiddende 
i Middelfart, blev kasserer. Foreningens formål var, som det blev beskrevet $i$ en trykt pjece, »at være vort tavse Hjemlands Mund, og vi har - naar vi slutter os sammen - Krav paa og Ret til at blive hørt $i$ alle Spørgsmål, der angaar vort Lands Fremtid. Endnu kan vi kun gøre lidt, da vi, som Forholdene foreløbig ligger, ikke kan virke offentligt i den Sag, der ligger os alle saa stærkt paa Hjerte. Men den Tid kan komme, da vi tør tale frit, og derfor skal vi ruste os i Tide «. ${ }^{13}$ Foreningens formål var at være beredt på eventuelle muligheder for politiske forandringer i Sønderjylland, med andre ord muligheden for at Sønderjylland igen kunne blive dansk. Om foreningen havde en direkte relation til den konservative studenterforening To Lover vides ikke, men det er overvejende sandsynligt. Foreningen To Løver var stiftet i 1888 af konservative akademikere i København med henblik på at styrke og gavne danskheden i Slesvig. Under krigen blev hjælp til unge sønderjyder, der enten var endt som krigsfanger i Ententelejre eller var deserteret til Danmark, en hovedopgave for foreningens medlemmer. Det var folk som rektor for Efterslægtselskabets Skole H.P.Hansen, overkirurg Ionas Collin, gymnastikdirektør N.H.Rasmussen, landsformand for Konservativ Ungdom Aage Kidde og den unge politiker John Christmas Møller. Kredsen var stort set identisk med de personer, der senere stod bag Dannevirkebevægelsen og som sådan virkede for en grænse ved Dannevirke. Holger Andersen, kasserer for Vort Hjemlands Vel, blev også en aktiv skikkelse i Dannevirkebevægelsen og kan have været kontaktleddet mellem de to foreninger. At en forbindelse synes mulig, hænger også sammen med Oluf Wolfs sideløbende aktiviteter. Foreningen To Løver forsøgte at skaffe sig overblik over tilstedeværelsen af sønderjyske desertører i Danmark og fordelte hertil en blanket, som desertørerne skulle udfylde med navn, fødested og opholdssted i Danmark. Denne informationsindsamling havde flere formål. Den var for det forste en forudsætning for at kunne yde desertørerne materiel hjælp. For det andet var informationerne, som Svend Falkner Sørensen har påvist, et led i en evakueringsplan i tilfælde af en tysk invasion af Jylland. En sådan var rent faktisk under overvejelse $\mathrm{i}$ den tyske hærledelse $\mathrm{i}$ foråret og sommeren 1917. For det tredje er det en mulighed, at informationerne på blanketterne kun var de første oplysninger, der søgtes. Desertørerne havde måske flere oplysninger at give, som ikke blev skrevet ned. ${ }^{14}$ I sommeren 1916 var Oluf Wolf netop blevet involveret $i$ indsamling af sådanne oplysninger. 


\section{Holger Christian Petersen - den franske forbindelse}

Spionageaktiviteter er i sagens natur vanskelige at kortlægge. Alt er hemmeligt, og frigivne oplysninger ikke nødvendigvis korrekte. Når der findes oplysninger om spionageaktiviteterne ved Kongeågrænsen under 1. Verdenskrig, er det fordi en del af de implicerede blev anholdt af det danske politi i foråret 1918 og efterfølgende stillet for en domstol, Københavns Kriminal- og Politiret, tiltalt for at have overtrådt lov af 2. august 1914 om tillæg til almindelig borgerlig straffelov af 10 . februar 1866 vedrørende hjælp til samling af oplysninger til fordel for krigsførende magt. Retssagens baggrund og udgang vender vi tilbage til. I første omgang er det mere interessant, at retssagen efterlod udtalelser fra de implicerede om deres spionageaktiviteter. Referater fra retssagen løfter således en del af sløret for grænsespionagen, omend udtalelserne fortsat er behæftet med usikkerhed. De tiltalte havde jo også muligheden for ikke at udtale sig om alle dele af spionagen. Blandt de anholdte og afhørte var Oluf Wolf, og i retssagsdokumenterne findes udtalelser af Oluf Wolf om dennes spionagevirksomhed, der kan sammenholdes med de øvrige afhørtes udtalelser. Af dokumenterne fremgår det klart, at Oluf Wolf havde en fremtrædende rolle i spionagenetværket.

Oluf Wolfs indgang til spionagen og væsentligste forbindelse til efterretningsvæsenet var en vis Holger Christian Petersen, der også stod anklaget $i$ april 1918. Blandt retsdokumenterne findes et forsvarsindlæg af Holger Petersens advokat, overretssagfører William Hauberg, der beskriver hans historie. Holger Christian Petersen var født $\mathrm{i}$ Nakskov i december 1882. I 1904 rejste han til Frankrig for at gøre karriere som handelsmand $\mathrm{i}$ træbranchen. Ifølge en udtalelse af den danske konsul Skram i Le Havre i 1913 havde Holger Petersen succes og formåede at komme $\mathrm{i}$ forbindelse med mange franske papirfabrikanter. Fra 1909 til 1913 opholdt Holger Petersen sig i Hamborg, men i 1913 flyttede han tilbage til Frankrig. Efter krigsudbruddet $i$ august 1914 anmodede Holger Petersen den danske konsul om at måtte blive indkaldt ved mobiliseringen i Danmark. Da det ikke lod sig gøre, meldte han sig frivilligt hos den franske hær. Et dårligt syn betød imidlertid, at han blev kasseret. Herefter forsøgte han sig hos den belgiske hær, der imidlertid ikke optog udlændinge. I efteråret 1914 kom Holger Petersen i kontakt med senator Brindeau, der i avisen Le Journal Du Havre havde skrevet en artikel om Danmarks vanskelige stilling mellem Ententen og Cen- 
tralmagterne (Tyskland, Østrig-Ungarn, Tyrkiet og Bulgarien), hvori han havde udvist sympati for Danmark. Brindeau, der var medlem af det franske senats udenrigskommission for skandinaviske anliggender, foreslog Holger Petersen, at han skulle gøre tjeneste som tolk hos englænderne. Heller ikke dette engagement blev til noget. I mellemtiden havde Holger Petersen gjort forretninger med den danske konsul Lillelund i Rouen, der repræsenterede det danske firma »De private Assurandører«. Holger Petersen optrådte som mægler i forbindelse med salg af cikorie i Danmark. Senere i 1915 blev han ansat af konsul Lillelund, der også gjorde sig i rederibranchen. Her var Holger Petersen sikret en god og sikker løn. På trods af dette lod han sig i marts 1916 overtale af en ven, der var fransk reserveofficer, til at tage til Danmark og her virke for det franske efterretningsvæsen for en løn på 500 danske kroner, senere 800 kroner, om måneden.

Ankommet til København henvendte Holger Petersen sig, efter ordre fra Frankrig, til Grev de Faramond og dennes adjudant og militærattaché, Roger Prevost, ved det franske gesandtskab. Grev Faramond bad her Holger Petersen om at skaffe oplysninger til det franske efterretningsvæsen på en måde, han selv fandt mest hensigtsmæssig. Holger Petersen fik, efter eget udsagn, ikke nærmere instruktion. Han traf efterfølgende en sønderjyde på sit hotel i København, der gav ham navnet på en anden sønderjyde, Theodor Mathiesen Kylling, "hvis bekendtskab han sikkert kunne have glæde af «. Dette møde har givetvis ikke været helt tilfældigt, og mon ikke franskmændene har skaffet den første forbindelse? Med denne oplysning i hænde tog Holger Petersen til grænseegnen og kom her i forbindelse med Kylling, »der vidste at han arbejdede for det franske gesandtskab«. I den første tid opholdt Holger Petersen sig i Kyllings hus ved grænsen. Her var der oplysninger at hente hos de tyske grænsevagter samt hos sønderjyder, der deserterede eller på anden vis kom over grænsen. De oplysninger, Kylling og Holger Petersen kunne skaffe, drejede sig fortrinsvis om tyske militære forhold, ernæringsforhold og landbrugsforhold. Oplysningerne blev efterfølgende sendt med post til Faramond i København. ${ }^{15}$ Således etableret kom Holger Petersen i kontakt med Oluf Wolf.

\section{Spionage}

Ifølge historikeren Tage Kaarsted var Danmark et spionagecenter under 1 . Verdenskrig, hvor det vrimlede med tyske, franske, russiske og 
engelske agenter. ${ }^{16}$ Oluf Wolfs historie viser, at der er noget om det. Her var der $\mathrm{i}$ hvert fald tale om både spionage, kontraspionage og infiltrationer i klassisk spionstil. Holger Petersen kom i kontakt med Oluf Wolf i sommeren 1916, formentlig via Kylling, på øen Fænø i Lillebælt. En tid derefter indgik Holger Petersen og Oluf Wolf en aftale om, at Oluf Wolf for en betaling på 200 kroner, senere $300 \mathrm{og}$ siden 500 kroner om måneden, skulle skaffe oplysninger om forhold i Tyskland ved afhøringer af dertil egnede folk, hovedsageligt sønderjyder. Wolf skulle sende de indhentede oplysninger til Holger Petersens adresse i København, hvorefter Holger Petersen ville aflevere dem til Roger Prevost på det franske gesandtskab. Oluf Wolf leverede i den følgende tid, efter Holger Petersens udsagn, en del gode oplysninger, særligt vedrørende forhold i Sønderjylland, såsom troppebelægninger, artilleristillinger, skyttegrave og lignende. Oplysningerne fik Wolf gennem afhøring af sønderjyder, der af den ene eller anden grund opholdt sig nord for grænsen. Det forekommer meget plausibelt, at det skulle være muligt for Oluf Wolf at skaffe oplysninger om forhold i Sønderjylland på den vis. Oluf Wolf gik dog længere ved at forsøge at skaffe "oplysninger om de forskellige værfter og deres nybygninger af krigsskibe, ubådenes basis og rute etc.«, som han udtalte ved retssagen i april 1918. Han fik, som han sagde, skaffet »fuldstændig oplysning om de sønderjyske skyttegrave«. En del heraf lå også på hans egen grund i Diernæs. De fleste af de afhørte fik ikke betaling for oplysningerne, og kun 10-20 kroner, hvis de trængte til det. De afhørte fik heller ikke at vide, at oplysningerne var til Ententens brug. Kun enkelte af de afhørte fik større beløb og også besked om oplysningernes anvendelse.

Det har ikke været muligt at opspore samtidigt kildemateriale fra selve spionageaktiviteterne. Det er meget muligt, at der i franske arkiver vil kunne findes materiale med oplysninger, der stammer fra Oluf Wolf. Forsøget er endnu ikke gjort. Det er derfor også vanskeligt at afgøre, hvor stor en værdi de af Wolf viderebragte oplysninger havde for franskmændene. Oluf Wolfs historie tyder dog på, at oplysningerne blev anset for værdifulde, ikke kun i Frankrig, men i lige så høj grad i Tyskland. Særlig synes oplysninger om tyske marineforhold at have været højt vurderet. Og dem kunne Oluf Wolf også skaffe. Under retssagen i april 1918 nævite Wolf tre personer, der alle havde fået betaling for deres oplysninger. Det drejede sig om henholdsvis Hans Peter Damm, Peter Nissen Bræraa og sognepræst i Vamdrup, 


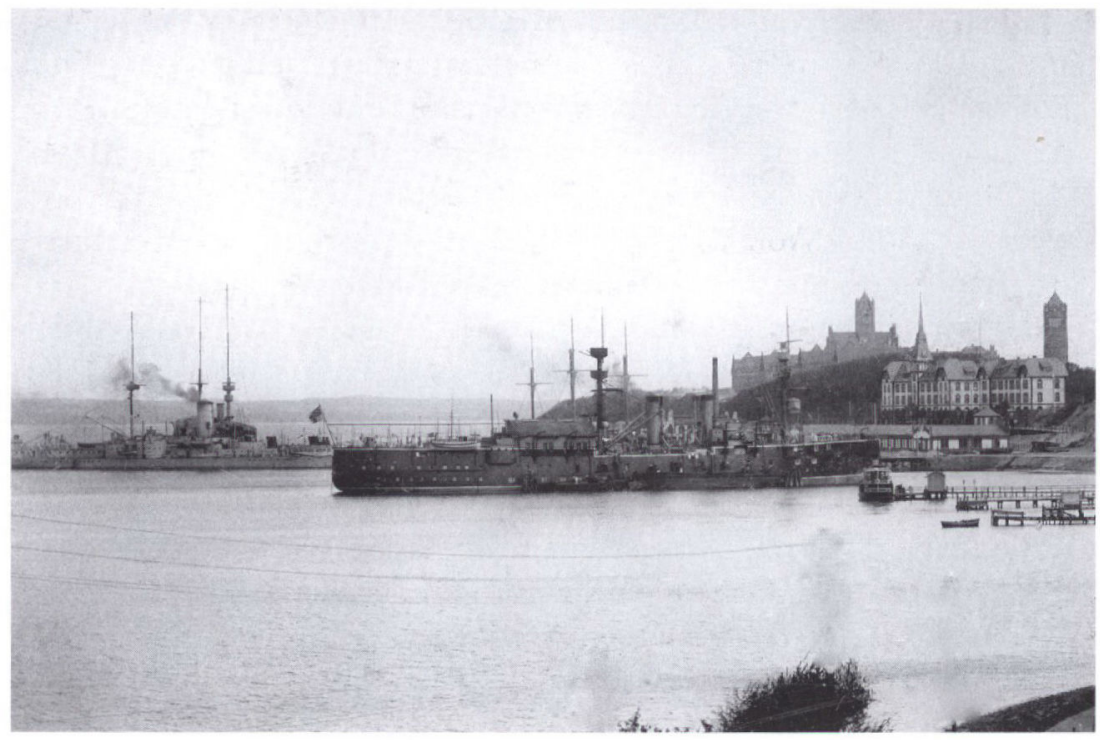

Tyske krigsskibe ved marineskolen Mürvik $i$ Flensborg Fjord omkring 1914. Oplysninger om den tyske flådes bevægelser $i$ Østersøen og $i$ Lillebælt var blandt de vigtigste af Oluf Wolfs informationer til den franske efterretningstjeneste. Foto: Arkivet ved Dansk Centralbibliotek for Sydslesvig.

Hans Mathiesen. Hans Peter Damm var sønderjyde og var deserteret under en orlov i september 1916. Han opholdt sig efterfølgende i Snoghøj. Ifølge Oluf Wolf havde Damm givet ham oplysninger 3-4 gange. Damm havde blandt andet leveret oplysninger om ubåde $\mathbf{i}$ Lillebælt. Damm havde også henvist Wolf til en sømand ved navn Davidsen i Fredericia, der gav gode oplysninger fra hans sejlads fra Emden til Fredericia samt om flyvemaskinehallerne i Flensborg, hvor han selv havde arbejdet. Damm havde yderligere henvist Wolf til to tyske sømænd ved navn Frantz og Stamp, som Wolf kunne tale med i Fredericia. Hans Peter Damm var desuden rejst til Stockholm på egen hånd og uden pas for at afhøre sin svoger, der var sømand på en Flensborgdamper. Svogeren kunne berette om en torpedohavn på den slesvigske østkyst samt om udvidelsen af en ubådshavn, også på den slesvigske østkyst. Oluf Wolf havde desuden talt med en tysk underofficer ved navn Brandt, der var deserteret til Danmark, men som gerne ville tilbage til Tyskland. Wolf havde aftalt med den tyske sømand Frantz, at denne tog Brandt med tilbage til Bremen. Endelig havde Wolf også kontakt med en tysk flyver, Laudi, der var interneret 
i Odense, og som var villig til at give oplysninger. ${ }^{17}$ Oplysningerne, der alle stammer fra retssagen i København, peger på, at Oluf Wolfs spionage primært drejede sig om marineforhold og militære forhold i Slesvig af forskellig art. Det må også formodes at være sådanne oplysninger, franskmændene var mest interesseret $i$.

Men hvad med det danske efterretningsvæsen? Det var såmænd også involveret, og blandt de afhørte i april 1918 var chefen for generalstabens efterretningssektion, kaptajn Erik With. Forbindelsen mellem Oluf Wolf og det danske efterretningsvæsen var redaktør af den nationalkonservative Kolding Avis, Erik Hansen. Erik Hansen havde efter eget udsagn modtaget artikler fra Holger Petersen før krigen og kendte på den vis manden, før han kom til Kolding. Under retssagen i København i april 1918 hævdede Erik Hansen, at Holger Petersen var begyndt at give oplysninger om forhold i Tyskland under et besøg i hans hjem. Holger Petersen havde her nævnt, at oplysningerne måske kunne have interesse for det danske efterretningsvæsen. Under de første forklaringer hævdede Erik Hansen, at han ikke vidste, at Holger Petersen arbejdede for det franske efterretningsvæsen. Han vidste heller ikke, at Holger Petersen lønnede Oluf Wolf for at skaffe oplysninger. Da Holger Petersen i sin forklaring hævdede, at Erik Hansen var blevet informeret herom, måtte Erik Hansen siden ændre sin forklaring. Erik Hansen bemærkede også, »at i Hovedsagen stammer alle de Oplysninger, han har sendt til det danske Efterretningsvæsen, fra Wolf «. Kaptajn Erik With bekræftede i sin forklaring at have modtaget oplysninger fra Erik Hansen i Kolding. Erik Hansen havde i den forbindelse nævnt Holger Petersen, men With var ikke klar over, at Holger Petersen var fransk agent og »havde navnlig ikke vidst at han havde engageret Wolf, og at de Oplysninger, den danske Generalstab fik, kom fra Wolf til Holger Petersen, fra denne til Erik Hansen og derfra til den danske Generalstab". Andet kunne af gode grunde heller ikke bevises. Det er dog en kendt sag, at With under krigen havde nær kontakt til Ententemagternes legationer i København, herunder den franske gesandt, Alexandre Conty, med henblik på at påvirke disse til fordel for en Dannevirkegrænse, ifald en mulighed herfor skulle opstå. Holger Petersens advokat, William Hauberg, skriver i sit forsvarsskrift, at Holger Petersen af den danske generalstab var blevet anmodet om at gøre generalstabens efterretningsvæsen delagtig $\mathrm{i}$ alt, hvad han kunne få at vide ved sin spionage. Erik Hansen var således blevet anvist som mellemmand. Flere af Oluf Wolfs kontakter, som Theodor Mathiesen 
Kylling og Hans Christian Mathiesen, hævdede under retssagen, at de af dem skaffede oplysninger kom det danske efterretningsvæsen til gode, og at det var det primære mål for deres aktiviteter. Oluf Wolf vedstod derimod uden betænkeligheder at have arbejdet for det franske efterretningsvæsen. ${ }^{18}$

\section{Kontraspionage}

En anden af Oluf Wolfs kontakter til det franske gesandtskab var gymnastikdirektør N.H. Rasmussen i København. N.H.Rasmussen havde på foreningen To Løvers vegne i 1915 rejst langs den sønderjyske grænse for, sammen med dr. Valdemar Harsløff, at samle adresser på sønderjyske desertører på de omtalte blanketter. Hensigten var at kunne advare sønderjyderne i tilfælde af en tysk invasion af Jylland. Men Rasmussen havde også andre hensigter. Under retssagen i april 1918 indrømmede Rasmussen at have ageret som forbindelsesled mellem de deserterede sønderjyder og Ententemagternes gesandtskaber. Forbindelsen bestod i, at Rasmussen henviste deserterede sønderjyder til at give oplysninger om tyske militære forhold på de respektive gesandtskaber $i$ København, enten ved at møde op på gesandtskaberne med sønderjyderne eller ved selv at sende oplysninger, han havde erhvervet fra sine forbindelser i grænselandet. Blandt disse forbindelser var læge Niels Marius Swith fra Ribe, pastor Mathiesen fra Vamdrup og Oluf Wolf. N.H. Rasmussen lagde, som Oluf Wolf, ikke skjul på sine Ententevenlige aktiviteter, da han stod tiltalt i april 1918. Rasmussens hovedmotiv havde været at opnå noget for sønderjyderne, ikke mindst begunstigelser for sønderjyske krigsfanger i Ententelandene. Her havde N.H. Rasmussen da også været stærkt medvirkende til, at der blev oprettet særlige lejre til sønderjyske krigsfanger i Frankrig, England og Rusland. Forbindelsen mellem Oluf Wolf og N.H. Rasmussen bestod i, at Oluf Wolf sendte desertører til N.H. Rasmussen i København, der efterfølgende sendte desertørerne videre til det franske gesandtskab. Ét eksempel på dette kom frem under retssagen i København. Det var til gengæld et helt særligt tilfælde.

Tyskland lå heller ikke efterretningsmæssigt stille i Danmark under 1. Verdenskrig. I sommeren 1921 kom det frem, at udenrigsminister Erik Scavenius i 1915 skulle have tilladt den tyske regering at indrette en "Spionabwehrabteilung" $i$ København i tilknytning til ge- 
sandtskabets paskontor. Scavenius begrundede efterfølgende tilladelsen med, at man fra tysk side havde ment at have vanskeligere spionagevilkår end Ententen på grund af befolkningens anti-tyske holdning. For ikke at blive beskyldt for ulige behandling af Tyskland havde Scavenius givet tilladelsen på betingelse af, at der ikke blev spioneret imod Danmark. ${ }^{19}$ Afdelingen skulle ifølge Scavenius være blevet nedlagt efter blot et års tid. Den tyske "Spionabwehrabteilung" nåede dog at krydse Oluf Wolfs spor. I oktober 1917 sneg en person af tysk herkomst ved navn Paul Richard Kulisch sig over den dansktyske grænse og fortsatte til København. Her kom han i forbindelse med Hans Persson, der siden august 1917 havde arbejdet som medhjælper ved det tyske paskontor i København. Kulisch blev engageret som medhjælper samme sted. Ved retssagen i april 1918, hvor Kulisch også stod tiltalt, kom det frem, at Kulisch blev betalt 250 kroner om måneden for at søge oplysninger om den mod Tyskland fjendtlige spionage i Danmark. I den egenskab rejste Kulisch til Kolding for at lade sig infiltrere som agent for Ententemagterne under dække af at være tysk desertør. I Kolding indfandt Kulisch sig på »Hotel Hvide Hest«, hvor han »klagede sin nød for værten og stillede sig ynkelig an«. Værten fik medlidenhed med Kulisch og tilbød at finde en mand, der kunne hjælpe Kulisch, hvis han ville vente. Senere på dagen blev Kulisch introduceret for to sønderjyder på "Hotel Hvide Hest«. De to sønderjyder var Oluf Wolf og Peter Nissen Bræraa. Wolf og Bræraa udspurgte nu Kulisch om militære forhold i Tyskland og gav ham efterfølgende rejsepenge med henblik på at rejse til København for her at opsøge gymnastikdirektør N.H. Rasmussen på dennes adresse, Vodroffsvej 51.

I København blev Kulisch budt til middag hos N.H. Rasmussen. Middagen blev indtaget $i$ selskab med en tredje person ved navn Charlot Chaussereon, der var en bekendt af Rasmussen. Chaussereon var født i Nancy i 1891, men havde studeret og aftjent værnepligt i Tyskland som frivillig. Han blev indkaldt ved krigsudbruddet i august 1914 og blev siden såret på vestfronten. I 1916 lykkedes det Chaussereon at flygte over grænsen til Danmark. Her havde Chaussereon været beskæftiget med franskundervisning og korrespondance for Røde Kors. Sideløbende med dette havde Chaussereon, i samarbejde med N.H. Rasmussen, været engageret $\mathrm{i}$ at skaffe oplysninger om tyske militære forhold, særligt ved at afhøre sønderjyske desertører. Ved middagsmåltidet hos N.H. Rasmussen blev der talt om, hvor- 


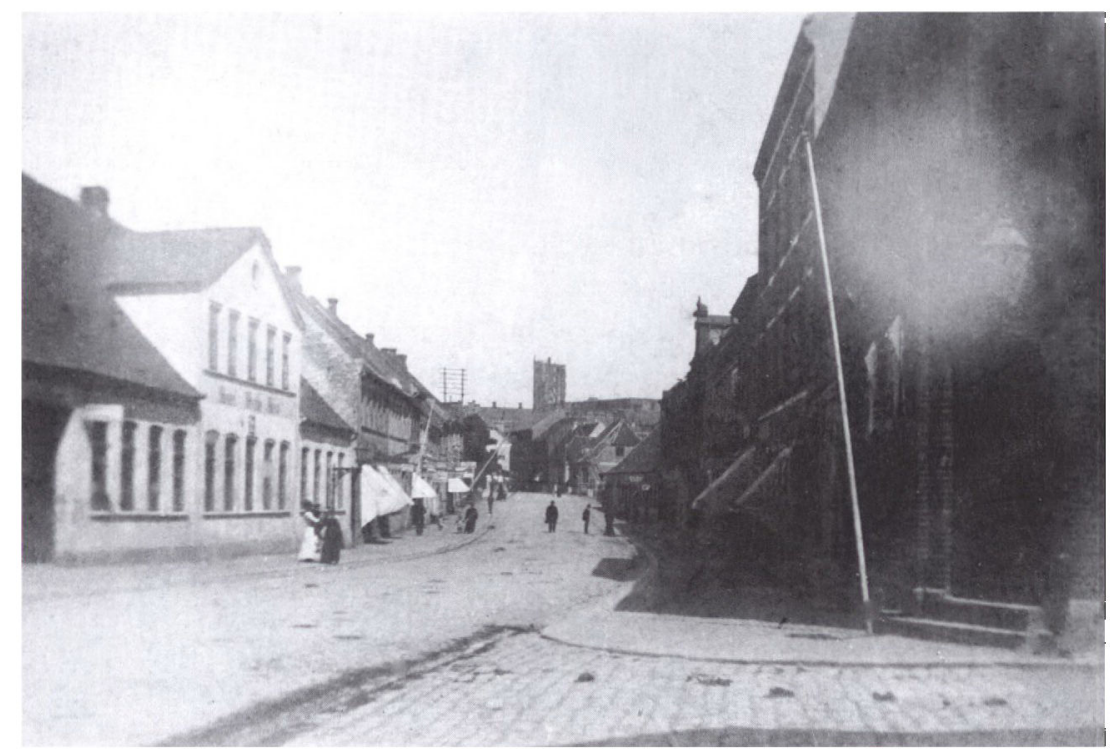

"Hotel Hvide Hest « på Sondergade i Kolding omkring 1910. Det var her, Oluf Wolf mødte den tyske dobbeltngent Kulisch $i$ efterăret 1917. Foto: Kolding Stadsarkiv.

ledes Kulisch kunne hjælpes. N.H. Rasmussen ønskede ikke støtte Kulisch, da han ikke var sønderjyde. I stedet tog Chaussereon Kulisch med til det franske gesandtskab, hvor han efter forhandlinger blev engageret som fransk spion mod en månedlig betaling på 300 kroner. Som sådan kunne Kulisch fodre franskmændene med falske oplysninger. Sammen med Hans Persson på det tyske paskontor, der forblev Kulisch's tyske forbindelse efter infiltrationen, planlagde Kulisch at lokke Chaussereon ombord på et tysk skib i Karrebæksminde for at føre ham tilbage til Tyskland. Chaussereon havde dog fattet mistanke og var ikke mødt op. Ifølge Udenrigsministeriets referat af sagen var det franske gesandtskab på forhånd blevet informeret om Kulisch's dobbeltagentrolle. ${ }^{20}$

\section{Retssagen i København}

Hvordan spionageaffæren præcist endte med at blive delvist trevlet op i Københavns Kriminal- og Politiret i april 1918, fremgår ikke helt klart af kilderne. Ifølge Tage Kaarsted havde den tyske gesandt, grev 
Brockdorff-Rantzau, i foråret 1918 klaget over, at chefen for generalstabens efterretningssektion, Erik With, forsynede Ententelandenes legationer med spioner, hvilket skulle have foranlediget en retslig undersøgelse. ${ }^{21}$ Det er imidlertid også muligt, at det var generalstabens efterretningssektion, og dermed Erik With selv, der foranledigede retssagen. Ifølge Udenrigsministeriets referat af sagen var det generalstabens efterretningssektion, der blev opmærksom på Paul Richard Kulisch's spionvirksomhed, og som henledte politiets opmærkomhed på ham. At både Paul Richard Kulisch og Hans Persson fra det tyske paskontor stod anklaget $\mathrm{i}$ april 1918 taler herfor. I modsat fald skal man fra tysk side have været villig til at ofre de to spioner mod til gengæld at få stoppet den franske spionage. Det er på den anden side heller ikke usandsynligt. Hvorom alting er, stod hele flokken på anklagebænken i april 1918. Flokken bestod af Paul Richard Kulisch, Hans Persson, Charlot Chaussereon, Holger Christian Petersen, Oluf Peter Wolf, Peter Nissen Bræraa, Hans Peter Damm, N.H. Rasmussen og kaptajn Erik With. Dertil kom sognepræst A.V.Storm, rektor H.P. Hansen, fuldmægtig Richard Høgh Brask, boghandler Peter Jacob Hansen Fergo, dr.med. Ionas Collin, dr.med. Valdemar Harsløff, redaktør Erik Hansen, pastor Mathiesen, læge Niels Marius Swith, vognmand Nicolai Nielsen Schmidt, Theodor Mathiesen Kylling samt Hans Christian Mathiesen og Boy Jessen. Alle blev sigtet for at have overtrådt lov af 2 . august 1914 om tillæg til almindelig borgerlig straffelov af 10 . februar 1866 vedrørende hjælp til samling af oplysninger til fordel for krigsførende magter. Den opmærksomme læser vil have genkendt størstedelen af foreningen To Løvers og senere Dannevirkebevægelsens aktive medlemmer blandt de sigtede. Det var ønsket om en Ententesejr med henblik på at vinde Sønderjylland tilbage til Danmark, der var baggrunden for kredsens involvering i spionagen.

Retssagen blev ledet af assessor ved Københavns Kriminal- og Politiret, Viggo Thorup. Thorup formåede gennem afhøringer af de tiltalte at få klarlagt mange dele af spionageaktiviteterne, som ovenstående har vist. Det lykkedes dog ikke at udpege en egentlig organiserende kraft bag spionagen, der indeholdt både Ententespionage, tysk kontraspionage og dansk spionage, uden klare skillelinjer. Chefen for den danske generalstabs efterretningstjeneste, kaptajn Erik With, stod også tiltalt. Han kunne imidlertid, meget belejligt, fralægge sig ansvaret for spionagen, da han blot havde modtaget oplysninger fra redaktør Erik Hansen i Kolding. Det jyske grænsedetachement afhør- 
te ganske vist også desertører på efterretningssektionens vegne, men at den franske agent havde hvervet de samme mennesker, kunne With ikke tage ansvar for. ${ }^{22}$

Der blev imidlertid aldrig afsagt dom i sagen. Den 7. maj 1918 modtog assessor Viggo Thorup en note afsendt af Justitsministeriet, der bad ham om at stille sagen i bero, "dog saaledes, at Tiltale ubetinget vil blive rejst mod samtlige Sigtede, hvis den under Sagen klarlagte lovstridige Virksomhed overfor syd fra kommende Desertører paa nogen Maade fortsættes«. Ministeriet påtænkte dog at udvise Charlot Chaussereon og forventede, ved Udenrigsministeriets mellemkomst, at Holger Christian Petersen kunne modtages i Frankrig. ${ }^{23}$ Den 10. maj 1918 blev Oluf Wolf, Hans Peter Damm og Peter Nissen Bræraa som følge heraf løsladt. De øvrige sigtede blev løsladt i løbet af de næste fire dage. Chefen for generalstabens efterretningssektion, kaptajn Erik With, blev samtidig forfremmet til oberstløjtnant og, mere væsentligt, forflyttet fra efterretningssektionen til Holbæk.

Hvorfor blev retssagen indstillet? En fortrolig notits stilet til det tyske udenrigsministerium, Auswärtiges Amt, og skrevet af den tyske gesandt Brockdorff-Rantzau den 17. maj 1918, giver et svar. Brockdorff-Rantzau refererer i notitsen en samtale med den danske udenrigsminister, Erik Scavenius. Scavenius havde i samtalen fortalt, at en vidt forgrenet spionageorganisation var blevet afdækket, hvori to tyskere, sekretæren for det tyske paskontor, Hans Persson, og en faneflygtning ved navn Kulisch, havde spillet en rolle. Brockdorff-Rantzau havde, naturligvis, aldrig hørt om de to. Kammerherre Zahle havde dog for nylig talt med ham om sidstnæunte og bedt ham sørge for, at Kulisch blev sendt tilbage til Tyskland. Scavenius havde yderligere berettet, at spionageorganisationen fortrinsvis bestod af personer fra det bedre borgerskab med forbindelser til Nordslesvig og til chauvinistiske foreninger som To Løver. Scavenius havde nøje overvejet, hvorledes sagen skulle behandles, da en offentlig proces ville medføre en politisk skandale. De skyldige ville miste deres embedsstilling, såfremt de besad en sådan, men derudover havde Scavenius anbefalet, at der ikke blev slået ned på de skyldige, og at sagen blev suspenderet. Med suspensionen ville Scavenius opnå to ting. For det første at de skyldige blev efterladt med et "damoklessværd" og dermed ikke kunne fortsætte deres spionagevirksomhed. For det andet at pressen ikke fik nys om affæren. Dertil havde Brockdorff-Rantzau svaret, at han forstod ministerens motiver, men at han også havde 
betænkeligheder ved sagens udkomme. Betænkeligheden bestod i faren for, at den tyske presse ville blive bekendt med sagen og dens udfald. I så fald ville gesandten skulle forklare Berlin det forhold, at "meine berühmte deutschfreundliche Regierung habe die grössten Schweinehunde straflos ausgehen lassen«. Scavenius forsikrede hertil gesandten, at straffeprocessen ville blive genoptaget, hvis sagen kom til pressens kendskab. Scavenius kunne desuden fortælle, at de involverede ikke havde modtaget betaling eller andre fordele for deres flygtningehjælp. Det så Brockdorff-Rantzau kun som bevis for »ihren gewissenlosen und gefährlichen Fanatismus«. Scavenius kunne yderligere berette, at det var chefen for generalstabens efterretningssektion, den nu forflyttede oberstløjtnant Erik With, der havde anmeldt spionageaffæren og dermed forårsaget retssagen. Brockdorff-Rantzau formodede, at det skyldtes Withs frygt for selv at blive anmeldt for spionage. Afslutningsvis havde Brockdorff-Rantzau fortalt Scavenius, at han havde erfaret, at tyske faneflygtninge, engageret af Ententen, var vendt tilbage til Tyskland med henblik på at drive spionage. Enkelte var dog blevet pågrebet, før de deserterede for anden gang, og havde under forhør afgivet udtalelser om organisationen. BrockdorffRantzau kunne derfor ikke garantere, at sagen ikke ville blive taget op af den tyske regering. I så fald lovede Scavenius, at retssagen ville blive genoptaget. ${ }^{24}$

Skal Brockdorff-Rantzaus notits tages for gode varer, var det således udenrigsminister Scavenius, der havde fåt stillet retssagen $\mathrm{i}$ bero med det klare formål at dysse sagen ned og undgå offentlighedens kendskab til spionageaffæren. Det handlede for Scavenius primært om at undgå, at Danmark blev trukket ind i en storpolitisk konflikt, der kunne bringe den danske neutralitet $i$ fare.

Det lykkedes imidlertid ikke at holde pressen væk. I maj 1918 rullede avisen Social-Demokraten de mere kulørte sider af spionagesagen frem under overskriften "Den store Spionageaffære". Social-Demokratens artikler betød dog ikke, at sagen blev genoptaget. Oplysningen om, at Erik With selv skulle have forårsaget retssagen, forekommer noget tvivlsom og kan være et forsøg på at lægge alt ansvar over på With. Interessant er det også, at Brockdorff-Rantzau giver udtryk for ikke at kende til de fra tysk side involverede, mens han på den anden side kender til pågribelsen af hjemvendte faneflygtninge i Tyskland, der under forhør havde berettet om spionageorganisationen i Danmark. Det var et forhold, der skulle få betydning for Oluf Wolfs skæbne. 


\section{Oluf Wolf i Moabit-fængslet}

Efter at have sluttet fred på østfronten i december 1917 indledte Tyskland i foråret 1918 en fornyet offensiv på vestfronten, der en tid så ud til at lykkes. Men sidst i juli 1918 vendte krigslykken, og Ententemagterne pressede Tyskland tilbage. De tyske ressourcer, militære såvel som civile, var udtømte, og i efteråret 1918 blev det klart, at Tyskland ville tabe krigen. På gården Skærbæk gav det håb om, at Oluf snart kunne vende hjem. Oluf Wolf selv overvejede på dette tidspunkt at sælge gården for at købe en gård på Århusegnen. Det blev der ikke noget af. I stedet tonede spørgsmålet om den nye grænse frem. Det optog naturligvis Oluf. Vælgerforeningens tilsynsrådsmøde den 17.18. november tegnede til at blive afgørende for grænsespørgsmålets løsning. Den 15. november var tilsynsrådsmedlemmerne fra Haderslev kreds kaldt til møde i Hejls nord for grænsen for at drøfte grænsespørgsmålet med blandt andre rektor H.P.Hansen og Oluf Wolf. »De stod, skønt de havde været under stærk Pression, vedvarende fast i Grænsespørgsmålet«, som rigsdagsmand H.P. Hanssen skriver om Anders Lebeck og de øvrige medlemmer fra Haderslev i sine erindringer. Oluf Wolf stod ikke overraskende på Dannevirkebevægelsens standpunkt i grænsespørgsmålet.

Den 11. november 1918 skrev Tyskland under på en våbenhvileaftale, og 1. Verdenskrig var slut. Men Sønderjylland var fortsat under tysk herredømme. Ventetiden har formentlig været ulidelig for Oluf Wolf og andre i samme situation. I februar $1919 \mathrm{blev}$ tiden for lang, og Oluf Wolf vendte hjem til Diernæs. Det var en stor risiko at løbe, og i den første tid holdt Oluf sig også skjult. Et brev fra krigsretsrådet (Kriegsgerichtsrat) i Flensborg skrevet den 25. marts 1919 gav dog Oluf grund til at tro, at faren var drevet over. På basis af en henstilling fra Rådet for de Folkedelegerede var den indledte straffesag mod Oluf på grund af faneflugt frafaldet. ${ }^{25}$ Oluf ville ikke blive forfulgt på grund af sin faneflugt. Men Oluf Wolf havde ikke kun været faneflygtning.

Den 22. april 1919 blev Oluf Wolf anholdt ved gården Skærbæk af en tysk kriminalbetjent og den stedlige gendarm, Sbrzesky. Dagbladet Politiken berettede 6 dage senere om anholdelsen under overskriften "Sønderjysk Spionerisag? «: »I forrige Uge anholdt Politiet en Gaardejer Oluf Wolf fra Skærbæk ved Hoptrup. Han blev ført til Haderslev og indsat som Varetægtsfange i Amtsretsfængslet. Grunden til Anhol- 
delsen er antagelig en Sigtelse for Spioneri, og det er sandsynligvis et personligt Mellemværende mellem Wolf og en tysk Agent, der har givet Stødet dertil. Gaardejeren og Agenten har begge virket i Kolding, Wolf efter sigende som Agent for de Allierede, den Anden for Tyskland. Wolf har været $\mathrm{i}$ lange Forhør hos amtsdommer Karrasch. En af Byens Advokater, som af Fru Wolf var blevet anmodet om at bistaa den Anholdte, kunde ikke faa Indblik i Sagens Akter, hvorfor Advokat Ravn i Flensborg er blevet anmodet om at fore Wolfs Sag. Sagen vil blive overgivet til Rigsadvokaten i Leipzig. Wolf er kendt som en Person, der er ret uforsigtig med sine Udtalelser. Hans Navn har tidligere været nævnt i Forbindelse med en anden Spionerisag. ${ }^{26}$

Var det dobbeltagenten Paul Richard Kulisch, der havde angivet Oluf Wolf? I de breve, som Oluf Wolf i sin arresttid sendte til Margrethe, nævnes Kulisch ikke, men flere aviser nævner den tyske agent som årsag til anholdelsen. Sikkert er det, at det var den tyske admiralstab, der havde foranlediget anholdelsen. Den nye tyske gesandt $\mathbf{i}$ Kobenhavn, Konstantin von Neurath, var ikke informeret. Han bad den 27. april Auswärtiges Amt bekræfte nyheden, som han havde læst i Ribe Stiftstidende, om at Wolf var anholdt, og tilføjede, at han »in jetziger Lage halte für dringend erwünscht, dass Angelegenheit, wenn möglich, niedergeschlagen wird, da mit unliebsamen PresseErörterung zu rechnen «. Auswärtiges Amt var heller ikke informeret og bad landråden i Haderslev, von Löw, bekræfte anholdelsen. Von Löw bekræftede per telegram den 29. april, at Wolf var anholdt på foranledning af chefen for admiralstaben, og at en retssag var indledt. Auswärtiges Amt skrev efterfølgende til chefen for admiralstaben og bad om en bekræftelse på stabens rolle. Samtidig bad man admiralstabschefen overveje, om gennemførelsen af retssagen lige før en afgørelse af Nordslesvigs politiske fremtid nu også var hensigtsmæssig. Dertil svarede chefen for admiralstaben: "Gegen Wolf liegt hier umfangreiches Material zum Beweise seiner Tätigkeit für den feindlichen Nachrichtendienst während des Krieges vor«. Det var via en hr. Schmidt, der tidligere havde arbejdet for admiralstabens kontraspionagetjeneste, kommet til admiralstabens kendskab, at Wolf opholdt sig på tysk grund. Admiralstaben havde efterfølgende fremlagt sagsmaterialet for landråden i Haderslev og Statspolitiet, hvilket havde ført til en arrestordre på Wolf fra amtsretten i Haderslev. Efter arrestationen var sagen overgået til rigsadvokaten i Leipzig, der nu var ansvarlig for gennemførelsen af en retssag. Sagen var således ude af admiralstabens 


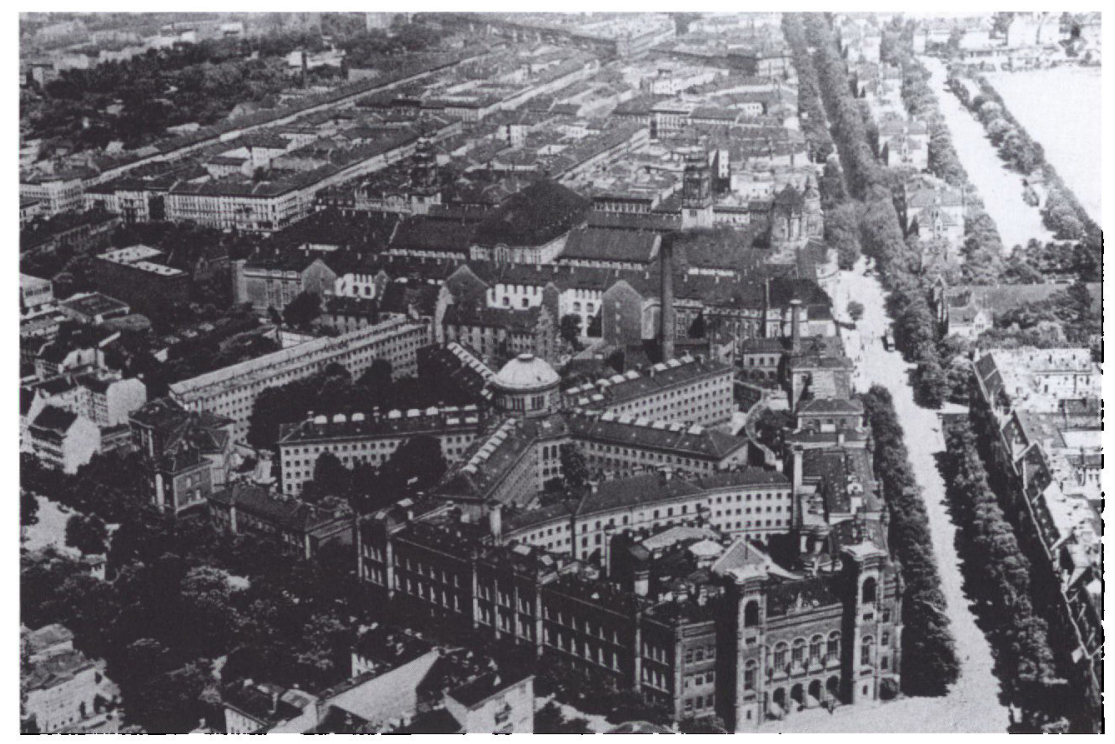

Moabitfængslet, den stjerneformede bygning i Berlin, hvor Oluf Wolf sad fængslet fra april 1919 til den 4. juni 1920, kun afbrudt af et ophold på et sindsygehospital. Luft foto fra 1925. Foto: Landesarchiv Berlin.

hænder. Hvis den nævnte hr. Schmidt var samme person som Kulisch, var Politikens beretning om anholdelsen korrekt. Mødet med Kulisch og den tyske kontraspionage i efteråret 1917 på »Hotel Hvide Hest « i Kolding var blevet skæbnesvangert for Oluf Wolf.

Auswärtiges Amt henvendte sig nu til rigsadvokaten i Leipzig med samme henvisning til de politisk uhensigtsmæssige følger af sagen. Rigsadvokaten kunne oplyse, at han havde iværksat forundersøgelser af sagen den 9. maj 1919, og at justitsråd og landretsdirektør Lilia ved 1. Landret i Berlin var udnævnt til undersøgelsesdommer. Anklagen mod Oluf Wolf var, at han under en mod det tyske rige udbrudt krig havde ydet en fjendtlig magt hjælp, da han i 1917 tjente England eller andre Ententemagter som spion. Hans ydelser bestod $i$ at henvise tyske desertører til den fjendtlige efterretningstjeneste samt $i$ at indsamle oplysninger fra tyske desertører, særligt fra matroserne Brandt og Schmidt, om flådebygning, skibsbevægelser, luftskibshaller og andre militære og for marinen vedkommende forhold samt $i$ at sende oplysningerne videre til den fjendtlige efterretningstjeneste. Wolf havde erklæret at være statsløs og dermed ikke skyldig, hvorfor statstil- 
hørsforholdet nu blev undersøgt. At der var politiske hensyn at tage, var for så vidt sagen uvedkommende, da rigsadvokaten var retsligt bundet til at gennemføre undersøgelsen. Han ville dog anmode undersøgelsesdommeren om at fremskynde sagen og om at være opmærksom på muligheden for at indstille sagen, såfremt bevismaterialet ikke lod sig bekræfte. ${ }^{27}$

Oluf Wolf klyngede sig, som rigsadvokaten skrev, til håbet om at blive erklæret statsløs på gerningstidspunktet i 1917. Havde han ikke været tysk statsborger, kunne han ikke straffes. Frem for alt klyngede Oluf Wolf sig til håbet om, at en fredsslutning mellem krigsmagterne ville føre til en løsladelse.

Oluf var blevet anholdt den 22. april og indsat $\mathrm{i}$ arresten i Haderslev. Den 27. april 1919 skrev Oluf et brev til Margrethe fra Moabitfængslet i Berlin, hvortil han var blevet overført. Her skulle Oluf sidde i over et år, før han igen blev løsladt. Under det ufrivillige ophold i Berlin skrev Oluf Wolf en række breve til Margrethe og børnene på Skærbæk, breve der er bevaret i familien. Brevene fortæller om en mand, der skiftesvis præges af håb og af dyb fortvivlelse. Brevene fortæller også om torturlignende tilstande, der tog særdeles hårdt på Oluf. I de første breve bekymres Oluf mest over familien. »For jeg er allermest ked af, at jeg giver jer så megen angst og bekymring, jer som jeg så gerne vil gøre glade og lykkelige«, som Oluf skrev den 3. maj. Margrethe modtog først brev fra Oluf i starten af juni og fik først her at vide, at Oluf befandt sig i Berlin. Hun rejste prompte til Berlin for at besøge sin mand sammen med sin far, et besøg der naturligvis glædede Oluf. »Hvilken glæde at se dig endnu en gang. Nu kan jeg med Guds hjælp holde det hele ud. Du må ikke være ked af, at jeg var så ubehersket. Lige før du kom, havde jeg et af mine allermest fortvivlede øjeblikke«, skrev Oluf den 13. juni. I juli 1919 rejste Margrethe og hendes far igen til Berlin. Udbyttet var et besøg i Moabitfængslet på 10 minutter.

Oluf og Margrethe satte deres lid til en fredsslutning og deraf følgende udleveringer af krigsfanger. Den 27. juni 1919, dagen før Tyskland underskrev Versaillestraktaten, skrev Oluf til Margrethe: "I går blev jeg igen afhørt. Min sag skal stå meget dårligt. Man har sagt mig, at freden ikke vil gøre nogen forskel for mig. Det har ængstet mig meget. Når den nye regeringskommission kommer til Flensborg, må den straks tage sig af min sag«. Versaillestraktaten skulle imidlertid først ratificeres af Ententemagterne, og det skulle som bekendt trække 


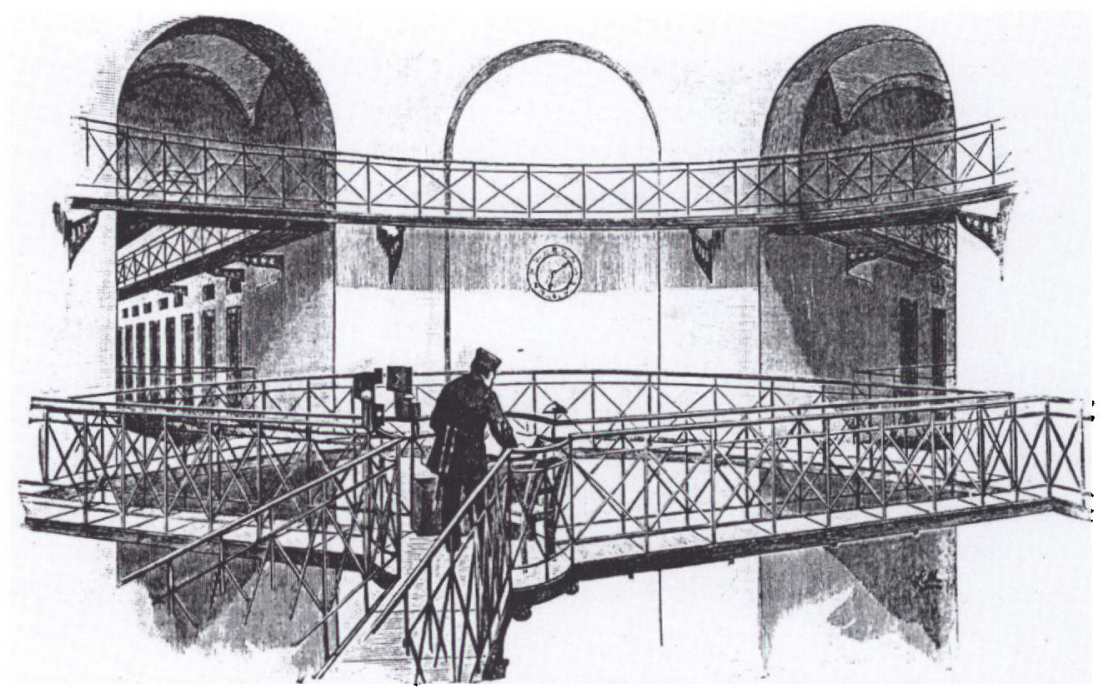

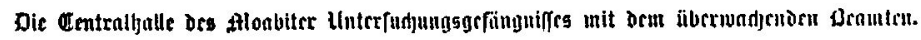

Moabitfangslet indefra. Historisk tegning af midtertårnet. Foto: Untersuchungsgefängnis Moabit, Berlin.

ud. En ansøgning om løsladelse mod kaution gav heller ikke resultat, endsige et svar. I august og september 1919 ændrer Olufs breve karakter og vidner om en mand under pres. Samtidig skrantede helbredet. "Min fod er så syg, og nu er det også gået op i benet. Til doktoren kan jeg ikke gå, og jeg kan vel også selv kurere det. Fængselslægen vil ellers tale med mig hver dag og er meget vred på mig, han vil lænke mig og sende mig i tugthuset. Han står i ledtog med officererne. Også om dig og børnene har han udspurgt mig. I må altså passe på. Min fod lader jeg ikke amputere. Det er svært at holde stand her. Men når du og børnene og alle mine kære blot kan leve $i$ fred og ro, så bliver jeg rolig. Nu bliver $\mathrm{i}$ jo snart danske, så har jeres nød en ende. - - Nej, min kære, her er ingen gode mennesker. Her er kun officerer og underofficerer. Præsten kommer ikke her, han er katolik og har ikke vores gud. Om Gud blot kunne finde mig her. Men gennem mit kældervindue kan jeg næsten ikke engang se hans himmel. Når Bertel kommer, må han hjælpe jer. - - - I længden kan dette her ikke gå, for de lader mig ikke fred en eneste nat «. Den 18. september var fortvivlelsen vokset. »Du har endnu så gode forhåbninger, min kære, men vi bliver skuffede, der vil endnu gå lang, lang tid. Jeg har 
overhovedet intet håb og ser slet ikke noget lys. Min fod er bedre, men jeg er bange for, at dette frygtelige mørke skal komme tilbage. Og de lange nætter er forfærdelige. - - - I forgårs var den tyske præst her, men da han hørte, at jeg var dansker, fór han væk fra mig, som om jeg var befængt med pest. - - - Jeg ville gerne dø, men jeg må først forsone mig med Gud, og så skal du holde mig i hånden «. Få dage før havde undersøgelsesdommeren anmodet Wolfs advokat, Christian Ravn i Flensborg, om, at Wolf måtte anbringes på et offentligt sindsygehospital til observation vedrørende hans mentale tilstand. Ravn var indforstået, og i november 1919 er Olufs breve afsendt fra III. Medizinische Irrenanstalt i Buch ved Berlin. I samme måned tog Margrethe og Olufs søster, Frederikke Wolf, til Berlin for at besøge Oluf. Her måtte de finde sig i kun at se Oluf gennem et vindue uden at få lov til at tale med ham. Fra den 20. november 1919 til 24. marts 1920 modtog Margrethe ingen post fra Oluf. Uroen i Tyskland, herunder post- og jernbanestrejker, er formentlig årsagen. Da han skrev igen i marts 1920 var han tilbage i sin celle i Moabitfængslet. Herfra skrev han: „Det er så umenneskeligt svært for mig at være i min snævre celle. Om jeg blot kunne nyde forårssolen, ville jeg med Guds hjælp sikkert blive rask igen. Om blot den længselsfuldt ventede Amnesti snart ville komme ${ }^{28}$

\section{"Wolf frei«}

Oluf Wolfs fængsling nærmede sig et års varighed. I mellemtiden var der flere, der arbejdede på hans løsladelse. Margrethe havde tidligt, på opfordring af Oluf, henvendt sig til H.P.Hanssen, der i juni 1919 var blevet minister for sønderjyske anliggender i den danske regering. Det var dog Den Internationale Kommission (C.I.S.), der skulle gennemføre afstemningerne i Slesvig, som Margrethe satte sin lid til. Om H.P. Hanssen har taget sagen op med kommissionen er uvist, men sandsynligt. Kommissionen samledes i København i august 1919 for at forberede afstemningerne, men først efter Versaillestraktatens ratificering den 10. januar 1920 kunne kommissionen installere sig i Flensborg. Kommissionens generalsekretær, Sir Charles BrudenellBruce, ankom til Flensborg den 14. januar sammen med det første hold af internationale besættelsestropper. Margrethe havde længe haft til hensigt at opsøge kommissionen i Flensborg for at tale sin mands sag. Den 20. januar rejste hun til Flensborg og mødte general- 


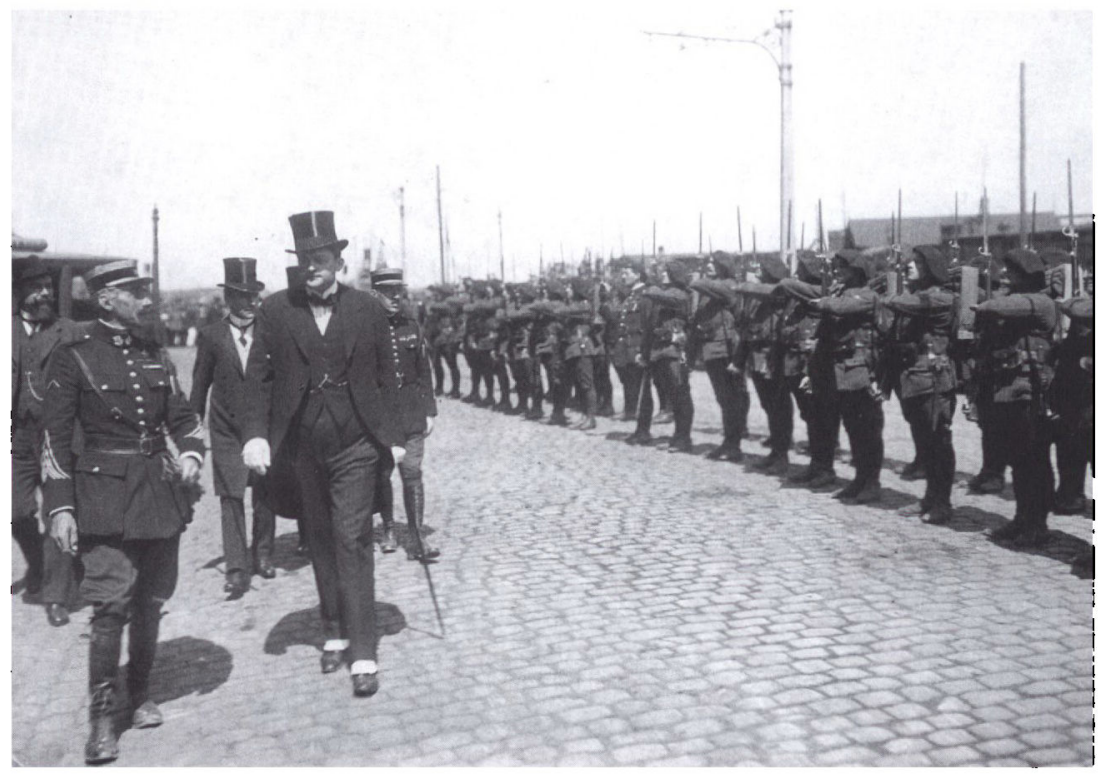

Charles Brudenell-Bruce, generalsekretær for C.I.S. (Den Internationale Kommission, der skulle gennemfore afstemningerne i Slesvig), inspicerer franske alpetropper på Flensborg Hain ved sin ankomst 14. januar 1920. Få dage senere modte han Margrethe Wolf, der bad Bruce om at hjxlpe Oluf ud af Moabit. Foto: Arkivet ved Dansk Centralbibliotek for Sydslesvig.

sekretær Brudenell-Bruce. "Jeg har været i Flensborg i dag, og nu er alting godt. $\AA$, kære gode Oluf, måske allerede i næste uge lovede de mig, at du kom hjem. Der er Amnesti, så nu skal vi være glade. Kommissionen er ikke kommen endnu, blot generalsekretær Bruce, og han kender dig gennem fru Slot Møller. Nej, hvor var han god og rar«, skrev Margrethe samme dag til Oluf. Selvom løftet om en uge var meget optimistisk, tog Brudenell-Bruce sagen alvorlig og henvendte sig til den tyske statskommissær for Slesvig, socialdemokraten Adolf Köster, der prompte reagerede ved per telegram at anmode undersøgelsesdommer Lilia om Oluf Wolfs løsladelse. En løsladelse ville være af stor politisk betydning, da Wolf var født i afstemningsområdet, begrundede Köster anmodningen. Det overbeviste på ingen måde undersøgelsesdommeren, rigsadvokaten i Leipzig eller den tyske udenrigsminister Hermann Müller. Sidstnævnte svarede Köster i et brev af 8 . februar, at selvom Wolf igen var erklæret rask, måtte undersøgelsesdommeren i henhold til \$154 i straffeloven gennemføre 
sine undersøgelser og sagen afsluttes ved dom. Det var ikke muligt for Auswärtiges Amt at lægge pres på domstolene, og en indstilling af sagen af politiske grunde var udelukket. Auswärtiges Amt kunne kun anbefale en fremskyndelse af sagen. »Im übrigen verdient Wolff keine besondere Rücksicht«, sluttede Müller, da Wolf havde udøvet fjendtlig og betalt spionagevirksomhed for Tysklands fjender. ${ }^{29}$

To dage før, den 6. februar 1920, var den danske gesandt i Berlin, Carl Moltke, blevet opsøgt af Margrethe Wolf, der bad ham træde ind i sagen for sin mand. Moltke havde efterfølgende afleveret en notits til understatssekretær von Haniel fra Auswärtiges Amt, hvori han anmodede om Wolfs frigivelse. Von Haniel havde vist forståelse for Moltkes synspunkt, men sendte få dage senere udenrigsminister Müllers svar til Köster i kopi, som svar på anmodningen. Senere i februar fik Moltke lejlighed til at drøfte sagen med udenrigsminister Müller, der også viste forståelse for de udenrigspolitiske uheldige aspekter i sagen. Müller havde bekræftet, at en benådning efter en domfældelse ville være en mulighed. Moltke forsvarede i øvrigt Oluf Wolfs sag over for udenrigsministeren, da han betegnede anklagen for erhvervsmæssig, det vil sige betalt, spionage for "sandsynligvis ubegrundet«. Nogen løsladelse førte samtalen ikke til, men Moltke slap ikke sagen af den grund. Den 16. februar skrev Moltke til udenrigsminister Erik Scavenius og gjorde ministeren opmærksom på en artikel i Nationaltidende af 27. januar under overskriften: „Oluf Wolf. Den Internationale Kommission griber ind, og han vil nu komme paa fri Fod «. Det var særdeles uheldigt, skrev Moltke, at Nationaltidende fremlagde forkerte oplysninger og gav indtryk af, at Den Internationale Kommission kunne presse den tyske regering $i$ sagen. Det kunne meget vel få det modsatte resultat.

I Udenrigsministeriet blev Wolfs sag nu også undersøgt, og et kig i retsdokumenterne fra april 1918 afslørede, at Wolf her havde indrømmet at have fåt betaling for sine aktiviteter. Den oplysning blev givet videre til Moltke med den tilføjelse, at han skulle have ventet på instruktion fra ministeriet, før han henvendte sig til de tyske myndigheder. Det kyste ikke Moltke, der den 19. februar på ny havde bragt Wolfs sag på tale i en samtale med understatssekretær von Haniel fra Auswärtiges Amt. For hver dag Wolf yderligere tilbragte i fængslet, voksede hans martyrstatus i Danmark, argumenterede Moltke. For sagens udvikling var det imidlertid af langt større betydning, at Margrethe Wolf havde bedt pastor Lindhardt, præst for den 
danske menighed i Berlin, om at skaffe Oluf Wolf en sagfører. Pastor Lindhardt havde i efteråret 1919 besøgt Oluf Wolf i Moabitfængslet i flere omgange og blandt andet forsynet ham med litteratur. Lindhardt havde henvendt sig til justitsråd Zeitschel, der havde erklæret sig villig til at tage sig af Wolfs sag. Moltke kunne desuden oplyse Udenrigsministeriet om, at Zeitschel var en personlig bekendt af undersøgelsesdommer Lilia, og at han havde ført andre lignende sager.

Sidst i februar henvendte den franske chargé d'affaires, M. de Marcilly, sig til Moltke. Han kunne meddele, at han af præsidenten for fredskonferencen havde fået ordre til at gøre en demarche, en diplomatisk henvendelse, for at opnå Wolfs løsladelse. Moltke og de Marcilly blev enige om, at Moltke i første omgang skulle lade oplysningen om demarchen tilgå understatssekretær von Haniel, således at den tyske regering fik mulighed for at fremskynde sagen mest muligt, inden demarchen fra Frankrig fandt sted. Forelagt dette, holdt von Haniel stadig fast på, at Auswärtiges Amt ikke kunne gribe ind i domstolenes arbejde, hvilket han også måtte svare den franske chargé d'affaires. Han ville dog igen arbejde på en fremskyndelse af sagen. M. de Marcilly havde efterfølgende meddelt Moltke, at demarchen ville blive afleveret således, »at unødvendig friktion undgås«.

Det blev heller ikke franskmændene, der fik Oluf Wolf løsladt, men derimod hans forsvarer, justitsråd Zeitschel. Den 26. april 1920 skrev Zeitschel til Moltke og sammenfattede sagens realiteter. Sagens forundersøgelser var afsluttet, og et anklageskrift kunne ventes snarligt. Wolf ville blive anklaget for at have overtrådt $\$ 89$ og $\$ 90$ i den tyske rigsstraffelov om spionage for fjendtlige magter under krig. Blev Wolf erklæret skyldig, ville han stå til minimum 10 års tugthusstraf, ved formildende omstændigheder minimum 5 års tugthusstraf. Oluf Wolfs chance for en frifindelse lå efter Zeitschels mening $i$ to forhold. Wolf havde for det første hævdet, at han ikke mente at være tysk statsborger på gerningstidspunktet. Han havde omkring juli 1916 læst i danske aviser, at tyske desertører, der vendte hjem før den 15. juli 1916, ikke ville blive strafforfulgt. Vendte desertøren ikke hjem, ville vedkommende miste sit tyske statsborgerskab. Ifølge Haderslev Kredsblad havde Wolf først mistet sit tyske statsborgerskab i juni 1918, og erklæringen om frit lejde for desertører var først afgivet den 29. maj 1917. Det udelukkede dog ikke, at Wolf i danske aviser kunne have læst, at han havde mistet sit statsborgerskab, hvilket kunne være en kendsgerning, der talte for hans frifindelse. Kunne en sådan notits 
findes $\mathrm{i}$ en dansk avis i tidsrummet juli til december 1916, ville det tjene Wolfs sag. For det andet var det afgørende, at Wolf $i k k e$ havde drevet erhvervsmæssig spionage og modtaget betaling for sine aktiviteter. Hvis den danske generalstabs efterretningssektion kunne bekræfte, at Wolf udelukkende havde handlet af patriotisk overbevisning og i øvrigt på ordre fra Erik With, ville det også øge chancen for en frifindelse. Wolf havde således hævdet, at han kun handlede på ordre af Erik With. Problemet med det sidste forhold var, at flere vidner havde hævdet det modsatte. Således havde Kulisch vidnet og $\mathrm{i}$ den forbindelse berettet om en samtale mellem N.H. Rasmussen og Charlot Chaussereon, hvor det blev sagt, at Wolf var en god agent, der skaffede mange oplysninger til franskmændene. Andre vidner, heriblandt gendarm Sbrzesky fra Hoptrup, havde hævdet, at Wolf tilsyneladende var blevet velhavende under sin faneflugt.

Via Moltke og Udenrigsministeriet blev generalstabens efterretningssektion i Danmark spurgt om deres forhold til Wolf. Sektionen bekræftede over for Udenrigsministeriet, at Wolf udelukkende havde handlet i patriotisk øjemed og ikke havde modtaget subsidier af de militære myndigheder. Det var også udelukket, at de modtagne oplysninger var gået videre til udenforstående. Efterretningssektionen ville dog meget nødig give en officiel udtalelse »i spørgsmaal af saa diskretionær Beskaffenhed «. Spørgsmålet var også, skrev sektionen, om Wolf overhovedet kunne dømmes for handlinger udført på dansk grund af en tysk domstol. Oplysningen om, at Wolf kun havde handlet af patriotisk overbevisning, kunne dog viderebringes til den tyske domstol.

På Moltkes foranledning blev avisnotitsen om Wolfs tabte statsborgerskab også efterlyst. Udenrigsministeriets pressechef, Marius Yde, skrev til redaktørerne af henholdsvis Kolding Avis, Ribe Stiftstidende og Flensborg Avis og bad dem søge notitsen deres aviser i tidsrummet fra 15. juli 1916 til 1. januar 1917. Ingen af de pågældende redaktører kunne finde en sådan notits. Erik Hansen, redaktør af Kolding Avis, der havde en del aktier i Oluf Wolfs skæbne, henviste til sønderjyske blade eller Amtsblatt. Avisnotitsen skulle imidlertid ikke blive nødvendig. Justitsråd Zeitschel blev pludselig og uventet kaldt til Rigsretten i Leipzig den 3. juni 1920, da der skulle afsiges dom i sagen mod Oluf Wolf. Sagen var blevet fremrykket på foranledning af Rigsjustitsministeren, men Rigsretten glemte i første omgang at informere Zeitschel derom, hvorfor Zeitschel kun fik 2 dages varsel. Zeitschel havde 
endnu ikke modtaget svar fra Danmark, hverken vedrørende avisnotitsen eller Wolfs patriotisme. $\mathrm{Nu}$ hastede det. Efter henvendelse fra Zeitschel telefonerede Moltke den 2. juni til Udenrigsministeriet og bad om en erklæring. Det lykkedes samme dag at indhente følgende erklæring fra Krigsministeriet: "Krigsministeriet erklærer, at det har sin Rigtighed, at Hr. Wolfs Virksomhed har været udelukkende af patriotisk Karakter, og at han ikke har modtaget noget som helst vederlag for sin Tjeneste af danske militære Myndigheder «. En avisnotits var det som omtalt ikke lykkedes at finde. Da justitsråd Zeitschel allerede var rejst mod Leipzig, måtte gesandtskabet i Berlin sende Krigsministeriets erklæring til Zeitschel per telegram. Samtidig blev meddelelsen også sendt per telegram til Rigsadvokaten i Leipzig. Nu ventede afgørelsen.

Den 4. juni 1920 modtog det danske gesandtskab i Berlin et telegram fra justitsråd Zeitschel der lød: "Wolf frei«. Senere samme dag ankom justitsråden til Berlin og kunne berette Moltke om sagens udfald. Oluf Wolf var blevet løsladt på grundlag af en amnestiforordning af 12. november 1918 udstedt af Folkerådet. Amnestien kunne anvendes, fordi Wolfs forbrydelse var af politisk og ikke af erhvervsmæssig karakter. Det havde været højst tvivlsomt, om Wolfs forbrydelse kunne falde ind under amnestien, men det var lykkedes Zeitschel at overbevise Rigsretten herom, ikke mindst ved hjælp af telegrammet med Krigsministeriets erklæring, som Zeitschel havde læst op for dommeren. Oluf Wolf var efter frifindelsen rejst med Zeitschel tilbage til Berlin og havde overnattet hos justitsråden. ${ }^{30}$

Justitsråd Zeitschels beretning blev sendt fra Berlin til Udenrigsministeriet i København den 5. juni. På følgeskrivelsen står der med håndskrift skrevet: "Bruce meddeler, Köster havde bestemt lovet ham, at Wolf ville blive fri. Efter hvad B. har erfaret skyldes frigivelsen personlig indgriben fra Kösters side«. Hvem, der har påført meddelelsen, er uvist. Om oplysningen holder vand er også uvist. Den 17. maj havde Brudenell-Bruce skrevet til Adolf Köster, der i marts 1920 var blevet tysk udenrigsminister, og tilføjede her $\mathrm{i}$ en bisætning: »I would also ask you whether you have any news of Oluf Wolf. I am very anxious about it for reasons we have often discussed «., ${ }^{31}$ Köster kan meget vel have fremskyndet sagen og presset på for en frigivelse. Det havde Auswärtiges Amt forsøgt siden anholdelsen af Oluf Wolf $i$ april 1919. Meget peger dog på, at det først og fremmest var justitsråd Zeitschel, Oluf Wolf kunne takke for sin løsladelse. Det var i hvert 
fald Zeitschels fortjeneste, at Wolf ikke blev dømt for erhvervsmæssig spionage på trods af, at han faktisk havde modtaget betaling af Holger Petersen for sine oplysninger til den franske efterretningstjeneste.

Søndag den 13. juni 1920 ankom Oluf Wolf til banegården i Haderslev efter mere end et års fængselsophold i Berlin. Margrethe havde modtaget ham i Flensborg dagen før, og i Haderslev ventede de 5 børn, Olufs to søstre, svigerforældre og venner. Det blev naturligvis et meget bevæget gensyn. Gensynet med moderen, Cathrine Marie, på Skærbæk var ikke mindre bevæget. Da kong Christian $X$ kom til Haderslev den 10. juli, var familien Wolf blandt de mange tilskuere. Oluf forte ved den lejlighed Cathrine Marie hen for at trykke kongen i hånden.

\section{Æreslegionens Ridderkors}

"Hovedsagen for mig var at hjælpe Ententen og derved Slesvig og Danmark til dets Ret. Og det var og er jeg overbevist om, at jeg gjorde bedre ved at gaa til Danmark og efter ringe Evne gavne Ententens Sag, end ved at gaa i Skyttegraven og kæmpe mod de Magter, jeg betragtede og endnu betragter som vort Lands befrier.« Således skrev Oluf Wolf i et indlæg i Haderslev-avisen Danskeren den 6. oktober 1921. Indlægget var en reaktion på en kronik i avisen Vestkysten den 27. september 1921 forfattet af den unge journalist og frontveteran Morten Kamphøvener. I kronikken anklagede Kamphøvener spionagen ved den dansk-tyske grænse for at have kostet sønderjyske menneskeliv. »I deres tyskfjendtlige og ententevenlige Iver glemte de gode Mænd, der var medvirkende til, at de sønderjyske Flygtninge afgav deres Forklaringer om militære Forhold, at de derved var medvirkende til at sætte Hundreder, ja, Tusinder af deres sønderjydske Landsmænds Liv paa Spil.“ Kronikken og Oluf Wolfs indlæg forărsagede en intens avisdebat i oktober 1921. Hejmdal og Politiken bifaldt Kamphøveners kritik, mens konservative blade som Nationaltidende, Danskeren og Kolding Avis støttede Oluf Wolfs udtalelse. H.P.Hanssen anklagede i Hejmdal spionagen for at have forhindret mange sønderjyder i at holde orlov fra krigen på grund af de tyske myndigheders frygt for yderligere deserteringer og spionage. Hejmdal mente desuden, at intet havde skadet Danmark så meget $i$ udlandet som Oluf Wolfs indlæg i Danskeren den 6. oktober. Dertil svarede Oluf i et nyt indlæg i Danskeren den 19. oktober: »Og jeg konstaterer at H.P. Hanssen og 


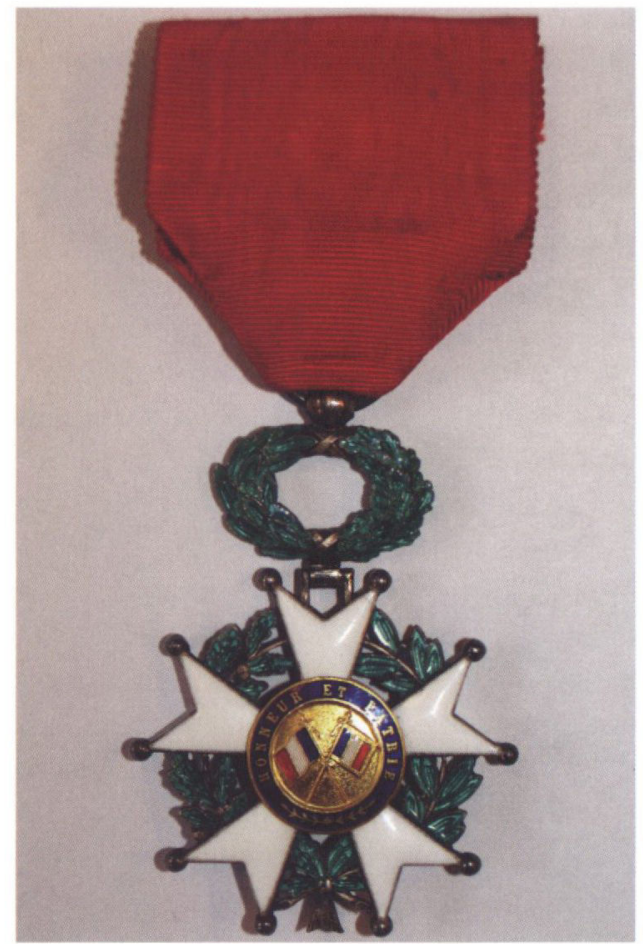

Areslegionens Ridderkors, som Oluf Wolf blev tildelt for sin spionage under 1. Verdenskrig. Privat foto.

hans Vaabendrager med Hensyn til Dommen i denne Sag er mere sensible og nøjeregnende end selve tyskerne«. Seminarielærer Claus Eskildsen, der også var frontveteran, sluttede sig til kritikken af »spionerne" med »den dybeste Afsky og Foragt og betegne dem som det de er, Mordere mod mange sønderjyske Landsmænd «. Eskildsen kunne give et eksempel fra kampene ved Moulin i sommeren 1915. Her led den tyske hær et stort nederlag, efter sigende på grund af, at oplysninger om fronten i et af en sønderjysk soldat skrevet brev var tilgået Ententens spioner. Det var rygter, der ikke lod sig bekræfte, og under alle omstændigheder havde Oluf Wolf ikke været involveret $i$ sommeren $19155^{32}$ Det var desuden ikke oplysninger om forhold ved fronten, Oluf Wolf havde leveret flest af, men derimod forhold vedrørende den tyske marine og militære forhold i Slesvig. Det var ikke uden grund den tyske admiralstab, der stod bag fængslingen af Oluf 
Wolf. At admiralstaben tog marinespionagen særdeles alvorlig, hænger sammen med det forhold, at det var kontrollen over de danske bælter og nordsøkysten, der var Tysklands primære interesse i forholdet til Danmark og admiralstabens ansvar. ${ }^{33}$

I efteråret 1921 høstede Oluf Wolf således skarp kritik for sine handlinger under krigen. Men der var oprejsning på vej fra anden side. Den 15. februar 1922 skrev den franske gesandt i København, Vicomte de Fontenay, til det danske udenrigsministerium, at den franske regering ønskede at dekorere 6 danske statsborgere med forskellige franske dekorationer. Som den eneste blandt de nævnte ville den franske regering tildele $Æ$ Ereslegionens Ridderkors til Oluf Wolf. Fontenay ville vide, om Udenrigsministeren havde nogen indvendinger imod dette. Det havde han. I et referat af sagen skitserede Udenrigsministeriet to muligheder. Enten skulle det franske gesandtskab bevæges til at erstatte noten med en anden, hvor Wolf ikke var anført. Eller også skulle noten besvares med udtrykkelig benævnelse af samtlige i noten nævnte undtagen Wolf. På referatet står der med håndskrift noteret: »Maa anse en Dekorering af Wolf for i høj Grad uheldig saavel for vor Forhold overfor Tyskland som overfor Frankrig, idet det danske Folk vil staa usympatisk overfor en saadan ganske upaakrævet Demonstration. Det maa herunder ikke glemmes den lidet tiltalende Rolle Wolf spillede i det forrige Aar af "Vestkysten" paabegyndte Angreb paa Spionagen under Krigen«. Udenrigsministeriet valgte derfor den sidstnævnte løsning, udelod Wolf i besvarelsen og håbede, at franskmændene ville gøre det samme. Den franske reaktion blev imidlertid ikke som forventet. Den franske chargé d'affaires i København, Allard de Chateauneuf, meddelte den 17. maj den franske udenrigsminister, at han i en samtale med det danske udenrigsministeriums direktør, O.C.Scavenius, havde ladet denne forstå, at Ereslegionen ville blive givet Wolf uden ministeriets accept. Da Wolf ikke var statsansat, var denne accept heller ikke påkrævet. O.C. Scavenius havde peget på den specielle art af tjenester, Wolf havde ydet, og på den polemik i pressen, tildelingen af Æreslegionen kunne medføre, med debatten fra oktober 1921 i erindring. Chateauneuf svarede hertil, at der var tale om gæld, Frankrig måtte betale tilbage. ${ }^{34}$

På Bastilledagen, den franske nationaldag den 14. juli 1922, modtog Oluf Wolf Æreslegionens Ridderkors af den franske gesandt, Vicomte de Fontenay, i det franske gesandtskab i København. Fontenay benyttede lejligheden til at prise det gode forhold mellem Danmark og 


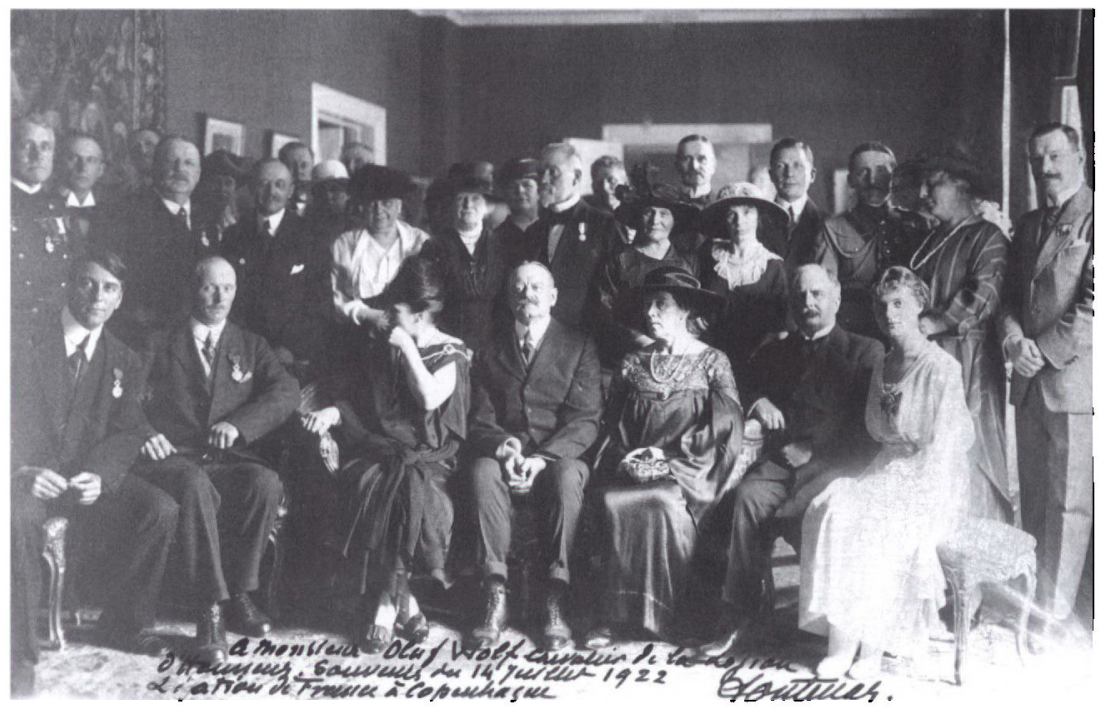

Den 14. juli 1922 modtog Oluf Wolf Ereslegionens Ridderkors på det franske gesandtskab $i$ Kobenhavn. Oluf Wolf sidder som $n r$. 2 fra venstre ved siden af skuespilleren Poul Reumert, der modtog Ridderkorset ved samme lejlighed. Gruppebillede underskrevet af gesandt Vicomte de Fontenay. Privat foto.

Frankrig. Oluf Wolf skrev få dage senere et takkebrev til gesandten med ordene: "Jeg er glad for at have kunnet tjene Frankrig og beklager kun ikke at have kunnet gøre endnu mere for Frankrigs sag, som i lige så høj grad var Danmarks og Slesvigs sag«. Dekoreringen udløste, som frygtet af Udenrigsministeriet, en reaktion i pressen. Denne gang også i Tyskland. Avisen Danskeren mente at vide, at løsladelsen af Wolf $i$ juni 1920 havde grundlag $i$ en fransk trussel om at ville likvidere tre tyske krigsfanger, såfremt Wolf ikke blev losladt. Det fik det tyske gesandtskab i Kobenhavn til at skrive til Auswärtiges Amt med den hensigt at få dementeret historien. Den 23. august 1922 bragte avisen Deutsche Zeitung en dementering. Oluf Wolf var udelukkende blevet løsladt på grundlag af amnestiforordningen af 12 . november 1918, da bevismaterialet havde vist, at spionagen var udøvet "nicht nur aus eigennützen, sondern auch aus politischen Beweggründen $\ll^{35}$

Modtagelsen af Æreslegionens Ridderkors var afslutningen på Oluf Wolfs spionagehistorie. Som indlægget i Danskeren den 6. oktober 1921 viste, stod han ved sine handlinger og havde intet fortrudt på 
trods af Moabit. At hans aktiviteter skulle have kostet sønderjyske liv, er da også meget tvivlsomt. Det var i sidste ende Oluf selv og familien Wolf, der betalte den højeste pris for spionagen. Oluf var mærket af opholdet i Moabit. Hans energi og engagement var ikke den samme som før krigen. Energien blev til rastløshed. Som mange andre sønderjyske landmænd fik Oluf Wolf økonomiske vanskeligheder i mellemkrigstiden. Han hørte til de genforeningskritiske røster blandt sønderjyske landmænd, men stod ikke i forreste linje af protestbevægelserne som hans bekendte fra krigen, Th. Kylling. I 1924 solgte Oluf slægtsgården Skærbæk til familiens og ikke mindst hans moders store fortrydelse. Han havde købt jord ved Hovgård i Hoptrup og byggede her Lille Hovgård. Købet og byggeriet gav Oluf Wolf store gældsproblemer, og han måtte låne penge af sin bror Bertel i USA for at kunne overholde terminerne. I 1926 måtte Lille Hovgård sælges til fordel for en mindre gård ved Hjaruplund. Familien trivedes ikke her, og i 1927 blev også denne gård solgt. I stedet købte Oluf Wolf Lille Søgård ved Farris, som sønnen Mathias overtog, da Oluf og Margrethe i januar 1941 købte hus på Christiansfeldvej i Haderslev.

Besættelsen af Danmark den 9. april 1940 vakte naturligvis stor ængstelse i familien. Oluf Wolf frygtede tyske repressalier og rejste op til sin svoger i Tvingstrup ved Horsens for at holde sig i skjul. Samme dag skulle tyske officerer, ifølge mundtlig overlevering, være mødt op på nabogården Store Søgård og have spurgt efter Oluf. Gårdejer Lund havde svaret, at Oluf Wolf var en gammel mand, og at tyskerne burde lade ham gå.

Der blev ikke siden spurgt efter Oluf. Oluf Wolf overlevede ikke Besættelsen, men døde den 26. marts 1943, 62 år gammel.

\section{FORKORTELSER}

RA: Rigsarkivet

LAÅ: Landsarkivet for Sønderjylland

\section{LITTERATUR}

Adriansen, Inge m.fl (red.) (2006): Sonderjyderne og den store krig 1914-1918. Historisk Samfund for Sønderjylland, Aabenraa.
GstA: Geheimes Staatsarchiv Preussischer Kulturbesitz

Bundgård Christensen, Claus (2009): Danskere på Vestfronten 1914-1918. Gyldendal, Kabenhavn.

Eliassen, P. (1980): Kongeden eller Den gamle granse. Toldhistorisk SelskabHistorisk Samfund for Ribe Amt.

Falkner Sorensen, Svend (1989): Fane- 
flugt? Dansksindede soldaters flugt fra tysk krigstjeneste 1914-18. Historisk Samfund for Sonderjylland, Aabenraa.

Fink, Troels (1979): Da Sønderjylland blev delt. Bd. 1-3. IFG. Aabenraa.

Hanssen, H.P. (1924): Fra Krigstiden. Dagbogsoptegnelser. Bd. II. Gyldendalske Boghandel. Kobenhavn.

Kaarsted, Tage (1973): Påskekrisen 1920. Aarhus Universitetsforlag.

Kaarsted, Tage (1975): Storbritannien og

\section{NOTER}

1. Denne artikel hviler på et stort forarbejde udfort af Viggo Kamp Nielsen, barnebarn til Oluf Wolf. Viggo Kamp Nielsen har i mange år arbejdet med Wolf-slægtens historie. Resultatet er det utrykte to-binds værk Wolfs Saga, der findes i Landsarkivet for Sonderjyllands manuskriptsamling, hvori en række af Oluf og Margrethes breve er citeret. De originale breve er i Viggo Kamp Nielsens varetægt.

2. Den Slesvigske Forenings formål var at virke for dansk sprog og danske undervisningsanstalters oprettelse i Slesvig, og den stod bag oprettelsen af Rødding Højskole $i$ november 1844. LAÅ. Rødding Højskoles arkiv. Pk. 253-254/1.

3. Frederik var opkaldt efter præst i Vilstrup Sogn 1850-59, Frederik Engelhardt Boisen, der havde konfirmeret Cathrine Marie i 1857. Frederik E. Boisen var grundtvigiansk og dansknational orienteret og har som sådan præget Cathrine Marie. Boisen blev kendt som "Budstikke-Boisen«, da han fra 1852 udgav tidsskriftet Budstikken - et folkeskrift til oplysning og opbyggelse.

4. Mens Sønderjylland var under preussisk administration 1867-1920, blev lægdsrullerne afløst af "alfabetiske lister«. Worsbe (1999), s. 73-81.

5. Kamp Nielsen.

6. De fem born var født i tiden fra 1907 til 1914, mens det sidste barn, Tove, forfatterens farmor, blev født $\mathrm{i}$ april
Danmark 1914-1920. Odense Universitetsforlag.

Kamp Nielsen, Viggo: Wolfs Saga og Wolfs Saga - Oluf Peter Wolf. Utrykt manusskript.

Lidegaard, Bo (2003): Overleveren 19141945. Dansk udenrigspolitiks historie. Bd. 4. Gyldendal. Kabenhavn.

Worsee, Hans H. (1999): Slægtshistorie $i$ Sonderjylland. Historisk Samfund for Sønderjylland, Aabenraa.

7. 1922 og døbt i Hoptrup Kirke. LAÅ. Kirkebog for Haderslev Frimenighedskirke 1895-1965.

8. LAA. H.P. Hanssens privatarkiv. Pk. $272 / 104$.

9. LAÅ. Hoptrup Amtsforstanders arkiv. Akthæfter fag XX. 66c Politische Vereine und Versamlungen sowie sonstige dänische Umtriebe.

10. Brev fra O. Wolf til Margrethe Johansen 10. juni 1903. Fra Kamp Nielsen.

11. Hejmdal 7. august 1914 og Falkner Sorensen (1989), s. 19.

12. Om faneflugt og deserteringer, se Falkner Sorensen (1989) og Bundgård Christensen (2009), s. 264-291.

13. Kamp Nielsen. Se også Adriansen m.fl (2006).

14. Kamp Nielsen.

15. Se Falkner Sørensen, s. 86-94, og Lidegaard (2003), s. 88-104.

16. RA. Justitsmin. 2. ekspeditionskontor 1918 samt LAÅ. Troels Finks privatarkiv. Pk. 87.

17. Kaarsted (1975), s. 134.

18. RA. Justitsmin. 2. ekspeditionskontor 1918 samt LA ̊. Troels Finks privatarkiv. Pk. 87.

19. Ibid.

20. RA. Udenrigmin. Arkiv. Gruppeordnede sager 13 y 68 .

21. RA. Udenrigmin. Arkiv. Gruppeordnede sager 13 y 70 .

22. Kaarsted (1973), s. 30-31.

23. Brev til Oberst Moltke 10/9 1919 fra Erik With. RA. Erik With og hustrus privatarkiv. Pk. 7 Diverse sager.

24. RA. Udenrigsmin. Arkiv. Gruppeordnede sager 13 y 70 .

25. RA. Håndskriftsamlingen XVI Dani- 
ca. Auswärtiges Amt. Deutsche Gesandtsschaft. Pk. 364.

26. Kamp-Nielsen.

27. Politiken 28. april 1919.

28. RA. Hăndskriftsamlingen XVI Danica. Auswärtiges Amt. Deutsche Gesandtsschaft. Pk. 364.

29. Brevene mellem Oluf og Margrethe skulle indtil december 1920 vare skrevet på tysk. Brevcitaterne er oversat af Viggo Kamp Nielsens hustru, Inge Kamp Nielsen, og findes i manuskriptet Wolfs Saga.
30. RA. Udenrigsmin. Arkiv. Gruppeordnede sager 13 y 66 .

31. Ibid.

32. RA. Danica-samlingen. CIS, FO $852 / 14$.

33. Se Bundgård Christensen (2009), s. 135-139.

34. Se Lidegaard (2006), s. $41 \mathrm{ff}$.

35. RA. Udenrigsmin. Arkiv. Gruppeordnede sager $49 \mathrm{~K} 97$.

36. GstA. I.HA. Rep. 77. Tit 4030. nr. 83. Dänischer Spionageskandal.

\section{Zusammenfassung}

Cirka 2.500 Nordschleswiger desertierten während des 1. Weltkrieges vom deutschen Kriegsdienst. Deserteure, die Frontdienst geleistet hatten, wussten viel über die Verhältnisse an der deutschen Kriegsfront. Die Ententemächte Frankreich, England und Russland nutzten dieses wertvolle Wissen durch ein Spionagenetzwerk nördlich der Königsau. Einer der Deserteure war Oluf Wolf aus Diernæs. 1915 entzog er sich in Dänemark dem deutschen Kriegsdienst und arbeitete von 1916 bis zum Frühjahr 1918 für den französischen Nachrichtendienst. Nach Kriegsende reiste er zurück nach Diernæs und wurde prompt verhaftet und der Spionage gegen sein Vaterland bezichtigt. Der Verfasser Morten Andersen schildert diese Begebenheiten, Oluf Wolfs Zeit im Berliner Gefängnis Moabit sowie die diplomatischen und juristischen Bemühungen bis zu dessen Amnestie im Juni 1920. 